\title{
LA TUTELA PENAL DE LOS ANIMALES ANTE EL MALTRATO: UN PROCESO EN TRANSFORMACIÓN ${ }^{1}$
}

\author{
Vicenta Cervelló Donderis \\ Universitat de València
}

\begin{abstract}
Sumario: 1.- Evolución del cambio social y legislativo en relación a los derechos de los animales 1.1.- Justificación de la tutela penal. 1.2.- Las claves de la reforma legislativa. 2.- Los nuevos contornos del delito de maltrato animal. 2.1.- ¿Animal objeto material o sujeto pasivo del delito? 2.2.- Estructura de la conducta y modalidades comisivas. 2.3.- Sistema de agravaciones. 3.- Consecuencias prácticas de la evolución en la interpretación de los elementos típicos. 3.1.- Ampliación del ámbito de aplicación. 3.2.- El umbral del sufrimiento como elemento diferenciador. 3.3.-La publicidad de los actos de maltrato. 4.- Penalidad. 4.1.- Sobre el cumplimiento o suspensión de la pena de prisión. 4.2.- Inhabilitación especial en relación a los animales. 5.- Conclusiones. Bibliografía
\end{abstract}

Resumen: En este trabajo se tratan los aspectos más relevantes de la reforma de los delitos de maltrato animal desde la perspectiva de transformación global de los derechos de los animales. Para ello se analiza la nueva estructura del delito, la ampliación del concepto de animal y el endurecimiento de la penalidad. Para completar su estudio se realiza un somero repaso de la jurisprudencia más reciente que revela el desarrollo de los elementos típicos y una mayor aplicación práctica.

Palabras clave: derechos de los animales, biocentrismo, maltrato animal, reforma penal, penalidad

Abstract: This paper analyses the main aspects of the reform of the crime of animal abuse from the perspective of a global transformation of animal rights. In order to do that, the paper deals with the new structure of the offence, the extension of the concept of «animal» and the harshening of the punishment. It will also review the recent

1 Trabajo realizado en el marco del proyecto de investigación DER2017-87943-R «Protección penal de la naturaleza y los bienes culturales». 
jurisprudence, which has revealed the development of the actus reus elements and the increasing of its application in practice.

Key words: animal rights, biocentrism, animal abuse, criminal law reform, punishment

\section{Evolución del cambio social y legislativo en relación a los derechos de los animales}

La protección de los derechos de los animales viene protagonizando en los últimos años una continua evolución. Desde su cobijo en las normas administrativas ha terminado llegando al Derecho Penal, donde si bien al inicio se le recibió con un cierto escepticismo, ha terminado asentándose como una figura delictiva que no deja de ampliar su ámbito de aplicación. Las razones que motivaban su rechazo se asentaban sobre su dudosa compatibilidad con el principio de intervención mínima del Derecho Penal, las dificultades para identificar un bien jurídico protegido autónomo no dependiente de otros, las diferencias entre los distintos tipos de animales como objeto de protección e, incluso, la existencia de ciertas prácticas y costumbres sociales que justifican actos de maltrato, sacrificio y explotación animal. Todo ello, sin embargo, no sirvió para frenar o limitar la recepción de este nuevo objeto de protección, sino más bien, al contrario, ha consolidado su expansión, lo que obliga a reflexionar sobre la justificación de la intervención penal en estos delitos con un doble foco de análisis, de un lado, la evolución que se ha producido en la resolución de conflictos sociales entre seres humanos y animales que parece dirigirse hacia la ponderación de derechos e intereses recíprocos y, de otro, el desarrollo que han observado los elementos típicos de esta figura delictiva y su contribución al esclarecimiento del ámbito de aplicación del delito.

El debate social que se ha generado en los últimos años sobre los actos de maltrato animal, y la discusión sobre la necesidad o no de su regulación en el ámbito penal, ha abierto una vía de reflexión y autocrítica sobre la ética del comportamiento de los humanos en sus relaciones de convivencia con los animales ante la proliferación de actos de sufrimiento animal ${ }^{2}$. Como tales se pueden considerar determinadas prácticas

2 Destacan el consenso alcanzado en no causar a los animales dolor innecesario ni maltratos injustificados FRANCIONE, G.L. «Personalidad, propiedad y capacidad legal» en CAVAlieri, P.-Singer, P. (Edición de) El proyecto gran simio. La igualdad más allá de la humanidad, trad. C.Martín y C.González, Ed. Trotta, Valladolid, 1998, pág. 311. Hava GARCía, E. «La protección del bienestar animal a través del Derecho penal», Estudios penales y criminológicos vol. XXI (2011), pág. 274. Muñoz Conde, F. Derecho Penal Parte Especial 21ª Ed. Tirant lo Blanch, Valencia, 2017, pág. 530. 
sobre animales que sin duda son conductas de maltrato ${ }^{3}$, las tradiciones sociales que utilizan el sufrimiento animal como mero divertimiento y las prácticas científicas o de experimentación que, pudiendo hacerlo, no evitan daños sobre los mismos.

De esta forma, la inicial cautela de la doctrina penal sobre el alcance de la protección de los derechos de los animales derivada de las dificultades encontradas para adaptar las categorías dogmáticas, más allá de los seres humanos para las que fueron concebidas, ha terminado admitiendo la necesidad de tutela penal para los casos más graves por considerar insuficientes las sanciones administrativas. Posteriormente se han producido numerosos cambios que han afectado al ámbito de lo punible, como un mayor número de conductas delictivas, nuevas agravaciones y la expansión de un objeto material, muy constreñido en sus inicios al animal doméstico de compañía, para acabar albergando a todo animal que tenga relación directa o indirecta con los seres humanos, más allá de la mera cohabitación ${ }^{4}$.

El proceso de transformación social que se está produciendo en la tutela penal del maltrato animal ${ }^{5}$ se puede analizar desde una doble perspectiva, desde el punto de vista de la fundamentación, se va abandonando paulatinamente la postura antropocentrista que cosifica a los animales como mero instrumento al servicio de los intereses humanos, a la par que va creciendo el auge de un biocentrismo moderado que reconoce derechos autónomos a la especie animal; y desde el punto de vista de la técnica legislativa, la regulación penal del maltrato animal se va aproximando a la regulación de las lesiones personales lo que aumenta las posibilidades de compartir criterios de interpretación.

En este contexto de cambios son tres los elementos que pueden ser considerados como determinantes: en primer lugar, un cambio ascendente en la percepción social de la protección de los derechos de los animales por la asunción de que las normas de convivencia entre humanos deben integrar en su seno el respeto a los seres vivos no humanos ${ }^{6}$; en segundo lugar, una voluntad legislativa de ampliar el ámbito de aplicación del maltrato animal que casi universaliza el objeto de protección reproduciendo en el delito de maltrato animal una estructura muy similar a la

3 Como el ahorcamiento de galgos en algunos lugares una vez finaliza la temporada de caza.

4 Ríos Corbacho. J.M. "Nuevos tiempos para el delito de maltrato de animales a la luz de la reforma del Código penal español (L.O. 1/2015)», Revista electrónica de Ciencia Penal y Criminología 18-17 (2016), pág. 32.

5 BRAge Cendán, S. «¿Es necesaria una nueva reforma penal en el ámbito de los delitos de maltrato y abandono de animales?», Diario La Ley $\mathrm{n}^{\circ} 9187$ de 27 de Abril de 2018, pág. 2.

6 Es destacable en este cambio el papel que desde 2012 está desarrollando el Observatorio de Justicia y Defensa Animal en el ámbito de la defensa, investigación y difusión de los derechos de los animales. 
regulación jurídica del delito de lesiones ${ }^{7} \mathrm{y}$, en último lugar, un cambio jurisprudencial que ha pasado de una postura muy restrictiva en el castigo de estas conductas a un mayor rigor en la aplicación de los tipos con un sensible aumento de sentencias condenatorias ${ }^{8}$.

Todo ello nos lleva a entender que se está produciendo una evolución social, legislativa y judicial que no sólo no considera de forma residual o simbólica el maltrato animal, sino que ha logrado invertir una tendencia negacionista, basada en las dudas que suscitaba la ausencia de objeto de tutela, para consolidar el reconocimiento general del bienestar animal como interés jurídico-penal, siendo buena muestra de ello la reforma penal de 2015 y sus modificaciones en relación al objeto, estructura y penalidad del delito. De esta forma, el análisis de la evolución que está sufriendo la tutela penal de los derechos de los animales en los últimos años no puede entenderse sin tener en cuenta los cambios legislativos en el orden internacional y nacional que han provocado una mayor sensibilización social, lo que exige centrarse en la particularidad de los animales como destinatarios de los ataques lesivos en el seno de las reformas penales más recientes, así como en las dificultades que pueden presentarse para la aplicación práctica de los respectivos tipos penales en sintonía con el principio de intervención mínima y demás principios penales.

A partir de esta reflexión previa, hay tres aspectos que requieren una especial atención: a) el proceso de transformación social en virtud del cual los animales han pasado de ser objetos de pertenencia de los seres humanos a ser sujetos de derechos, con sus correspondientes cambios legislativos; b) la problemática que plantea la progresiva aproximación de la regulación penal del maltrato animal a la regulación de los delitos de lesiones contra las personas y sus efectos sobre el desarrollo dogmático y su aplicación práctica; c) la adaptación de las sanciones previstas para el delito de maltrato animal a todas estas modificaciones.

\subsection{Justificación de la tutela penal}

La delimitación de un bien jurídico protegido propio y autónomo, como fundamentación del principio de intervención mínima, y la justificación de la necesidad de pena por la incapacidad de la protección en vía

7 Requejo Conde, C. «El delito de maltrato a los animales tras la reforma del Código penal por la ley orgánica 1/2015 de 30 de Marzo», Derecho animal (Forum of Animal Law Studies) vol. $6 \mathrm{n}^{\circ} 2$ (2015), https://revistes.uab.cat/da/article/view/v6-n2-requejo/77, pág. 1.

8 En 2018 se incoaron 1.121 procedimientos por delito de maltrato a los animales domésticos, de los cuales 224 fueron sentencias condenatorias y 44 absolutorias, lo que supone un aumento respecto a los años anteriores. En 2017 fueron 914 los procedimientos incoados, 163 fueron sentencias condenatorias y 46 absolutorias y en $\mathbf{2 0 1 6}$ de 774 causas que se incoaron, 103 fueron sentencias condenatorias y 28 sentencias absolutorias. https:// www.fiscal.es/documents/20142/a63c133c-dff3-6cf9-1a74-55d658be912a 
administrativa, son dos de los aspectos más controvertidos de la tutela penal del maltrato animal.

Desde una posición antropocéntrica se considera al ser humano como destinatario exclusivo de las normas destinadas a garantizar la convivencia pacífica a través de la regulación de derechos y deberes, siendo un paradigma de esta posición que los animales sean considerados en el Derecho Civil como cosas objeto de propiedad al primar en todo caso el interés del hombre por su consideración de provecho, fuente de riqueza o valor económico ${ }^{9}$.

La consideración de los animales como objeto de propiedad de los hombres, desde esta visión estrictamente antropocéntrica, dota a los animales de un mero valor instrumental sin reconocimiento de derechos propios y prioriza los intereses de los humanos sobre ellos, de esta manera, el rechazo al derecho a la vida y a la integridad física de los animales da lugar a que en las conductas de maltrato se protejan los sentimientos de las personas ${ }^{10}$, ignorando el sufrimiento del propio animal. Dicha situación es especialmente evidente cuando se limita la tutela penal al maltrato de animales domésticos, justificado en las especiales obligaciones de carácter bioético que exigen tratarlos de manera adecuada ${ }^{11}$, ya que además de ser un concepto cada vez más difícil de concretar, olvida la necesidad de tutela de otros animales que también gozan de la capacidad de sentir.

Desde esta perspectiva, las leyes de protección de los animales no crearían derechos subjetivos ni elevarían a los animales a una categoría similar a las personas ${ }^{12}$, sino que se ocuparían de regular los deberes y obligaciones de los humanos en su relación con los animales, siendo lo más positivo de esta postura el tránsito desde la consideración del animal como objeto personal a disposición de su propietario, a un tratamiento o enfoque de prioritario interés social y público. Por su parte, lo más negativo de esta posición sería su distanciamiento con el desarrollo teórico de los derechos de los animales desligados de su relación con los seres humanos y su vinculación con una lectura ética de la comunidad moral en la que confluyen tanto humanos como animales con capacidad de sentir.

En sentido diferente, desde una concepción animalista no se admiten diferencias entre derechos humanos y derechos de los animales partien-

9 Muñoz Machado, S. y otros Los animales y el Derecho. Civitas, Madrid, 1999, pág. 47-48.

10 Roca Agapito, L. en «Algunas reflexiones sobre los animales y el Derecho Penal. En particular el Art.631 del Código Penal», Actualidad Penal n 18, 2000, pág. 401.

11 Higuera Guimerá, J.F. "Los malos tratos crueles a los animales en el CP 1995», Actualidad Penal n 17, 1998, pág. 349.

12 Muñoz Lorente, J. "La protección penal de los animales domésticos frente al maltrato", La ley penal: revista de derecho penal, procesal y penitenciario $\mathrm{n}^{\circ} 42,2007$, pág. 17. Ríos Corbacho, J.M. «Nuevos tiempos...« 2016, cit. pág. 22. 
do de la comunidad de iguales, matizándose en una postura biocéntrica moderada que los animales tienen derechos en sentido débil dada la distinción entre «usos esenciales y usos no esenciales».

Desde la comunidad de iguales se defiende que los animales tienen derecho a la vida, a la libertad y a no ser sacrificados arbitrariamente, por ello, desde esta postura no se distinguen los derechos humanos y los derechos de los animales no humanos, al entender que los derechos de todos los seres vivos merecen ser respetados. La razón de este planteamiento es el rechazo a considerar a los animales como propiedad de los humanos que los tienen a su total disposición para fines de diversión, salud o utilidad laboral, abogando por suprimir la explotación a la que están expuestos los animales a merced de los humanos, y prohibir la tortura y el maltrato, en muchas ocasiones amparado por ancestrales costumbres culturales o modernas técnicas de experimentación científica ${ }^{13}$.

Este grado de protección máxima que reconoce derechos a los animales por sí mismos, al margen de su relación con los hombres, presenta algunas dificultades jurídicas entre las cuales se puede destacar que los derechos no puedan alcanzar a todos los animales por igual, siendo además difícil establecer categorías; que algunos derechos sean incompatibles con la naturaleza animal ${ }^{14}$, lo que impide su ejercicio por la exigencia de una capacidad volitiva o de comunicación; o que los animales tampoco tengan deberes.

En el seno del biocentrismo moderado se reconoce que los animales no pueden ser considerados simples objetos de propiedad, explotación o maltrato, sino que tienen derechos e intereses propios vinculados al bienestar animal ${ }^{15}$ por su capacidad de experimentar placer, dolor o sufrimiento $^{16}$. La diferencia de estos derechos con los intereses de los seres humanos ${ }^{17}$ puede provocar conflictos que deben ser resueltos con una ponderación recíproca en virtud de la cual, en ocasiones, se dará preferencia a los «intereses primarios o esenciales» de los seres humanos sobre los «intereses secundarios» de los animales, pero, en otras, podrá hacerse en sentido inverso ${ }^{18}$. Problemática será en este sentido la amplitud de los términos «usos esenciales o beneficiosos» para la sociedad

13 En este sentido el Proyecto Gran Simio en el marco de la comunidad de iguales entre humanos y simios defiende tres derechos básicos de los animales: vida, libertad y prohibición de la tortura CAVALIERI, P.-SINGER, P. (Edición de) El proyecto gran simio. La igualdad más allá de la humanidad, trad. C.Martín y C.González, Valladolid, 1998 pág. 12.

14 Muñoz Machado, S. Los animales... cit. pág. 75.

15 Pelayo González-Torre, A. "Sobre los derechos de los animales» Anuario de Filosofía del Derecho n ${ }^{\circ}$ 7, 1990 pág. 555. Ríos CoRBACHO,J.M. «Nuevos tiempos... « 2016, cit. pág. 26.

16 Así lo expresa, entre otras, la Ley 1/2003 de protección de animales de Andalucía.

17 De Lucas Martín, J. «En el bicentenario de Darwin ¿derechos de los animales no humanos? La barrera de la dignidad», Teoría \& Derecho no 6, 2009, pág. 16.

18 De Lucas Martín, J. «En el bicentenario... «cit. pág. 17. 
dada su dependencia de los criterios culturales y sociales de cada momento y lugar, que deberá corregirse siguiendo el criterio rector de evitar sufrimientos innecesarios a los animales ${ }^{19}$.

De esta forma, el reconocimiento de un determinado nivel de protección autónomo de los derechos de los animales encuentra en el ámbito penal como premisa previa la delimitación del interés jurídico objeto de tutela que supone el bien jurídico protegido.

Aludir al medio ambiente y recursos naturales como bien jurídico protegido en los delitos de maltrato animal no parece correcto, especialmente cuando se trata de animales domésticos o similares, ya que no existe relación entre estas conductas y la protección del equilibrio del ecosistema que en su caso protegería a los animales silvestres ${ }^{20}$, ni el maltrato de un animal en concreto puede suponer un peligro para la especie como elemento de la diversidad natural ${ }^{21}$. Tampoco parece satisfactorio hacer referencia al sentimiento de compasión de los seres humanos, lo que además de ignorar el sufrimiento del animal, prioriza las exigencias de deber jurídico más que la tutela de derechos, por eso, como superación de ambas posturas, la que respeta mejor el reconocimiento de derechos propios de los animales es la que atiende al derecho al bienestar entendido como ausencia de sufrimientos innecesarios, lo que contempla aquellas conductas de maltrato que afecten a su vida, salud, integridad ${ }^{22}$, e incluso dignidad ${ }^{23}$.

En este sentido se explicaría que la concepción antropocéntrica del medio ambiente, propia de las primeras interpretaciones de estos tipos delictivos, haya evolucionado hacia una visión más ecológica centrada en el desarrollo sostenible en el contexto de unas relaciones de convivencia que garanticen el respeto mutuo entre animales y humanos, lo que podría mantener su adscripción entre los delitos contra el medio ambiente, pero con un bien jurídico propio, recayente sobre la vida y la integridad

19 Pelayo González-Torre, A. «Sobre los derechos...» cit. pág. 556.

20 Muñoz Lorente, J. «La protección...» 2007, cit. pág. 9. Requejo Conde, C. «El delito de maltrato...» 2015, cit. pág. 10.

21 MANZANARES SAMANIEGO, J.L.»El maltrato de animales en el Ordenamiento penal español: una visión sistemática» Revista General de Derecho animal y Estudios interdisciplinares de Bienestar Animal 1 (2018) pág. 12.

22 Hava García, E. «La protección del bienestar animal...» 2011, cit. pág. 278. Cuerda ARnau, M ${ }^{\mathrm{a}} \mathrm{L}$. «Maltrato y abandono de animales» Comentarios a la reforma del Código Penal de $20152^{\text {a }}$ Ed. Dtor. J.L. González Cussac, Tirant lo Blanch, Valencia, 2015, pág. 1081. Olmedo de la Calle. E. Los delitos de maltrato animal. Tesis doctoral inédita. Valencia, 2017, pág. 154.

${ }_{23}$ Así lo mantiene la jurisprudencia, SAP de Madrid 287/2004, de 19 de Abril, SAP de Barcelona 382/2007, de 24 de Octubre, Sentencia del Juzgado de lo Penal ${ }^{\circ} 1$ de Vitoria 26/2019, de 28 de Enero, que destacan «la dignidad del animal como ser vivo» como bien jurídico de estas conductas. 
de los mismos animales, sin referencias de utilitarismo social ${ }^{24}$. De esta forma, mantener el art. 337 del Código Penal en el capítulo dedicado a la «protección de la flora, la fauna y los animales domésticos» no sería adecuado porque la evolución legislativa del delito ha terminado tutelando otras muchas categorías de animales más allá de los domésticos, siendo más correcto ubicarlo bajo la denominación de delitos contra los derechos de los animales, lo que atiende mejor al interés individual del bienestar animal.

Las dudas sobre la naturaleza penal de las conductas de maltrato animal se centran fundamentalmente en los inconvenientes para delimitar un bien jurídico específico ${ }^{25}$ y su discutible compatibilidad con el principio de proporcionalidad, lo que lleva a algunos autores a decantarse por la suficiencia de las sanciones administrativas, algo que serviría también para evitar la instrumentalización política de conductas que llegan al Derecho Penal con una finalidad meramente simbólica ${ }^{26}$.

Frente a estas críticas ha de admitirse que, descartando una equiparación de derechos entre personas y animales, la gravedad de ciertas conductas de maltrato animal y el sufrimiento innecesario que producen a los animales como seres vivos, pueden justificar la necesidad de tutela penal siempre que se respete, no sólo el carácter de ultima ratio del Derecho penal por la incapacidad de otras alternativas punitivas, sino también el principio de proporcionalidad respecto a la respuesta penal frente a otras figuras delictivas que afectan a los seres humanos. En este sentido, el bien jurídico protegido en las conductas de maltrato a los animales se va consolidando en los últimos años en torno al bienestar animal frente a actos de maltrato y sufrimiento innecesario ${ }^{27}$, manifestados en ataques a la integridad física, psíquica y salud de los animales

24 Vercher noguera, A. «Nuevas perspectivas sobre el bien jurídico protegido en los delitos medioambnetales, ¿cabría hablar de derechos no humanos de los animales domésticos frente al maltrato? Diario La Ley no 8994 de 6 de junio de 2017, pág. 9 y 14.

25 Muñoz Conde, F. lo considera un bien jurídico difícil de determinar Derecho Penal... 2017, cit. pág. 530. Marqués Blandú, M. «art. 337»Comentarios al Código Penal español Tomo II $7^{\text {a }}$ Ed. Dtor. G. Quintero Olivares, Thomson Reuters, Barcelona, 2017, pág. 869 y Martínez Buján, C. Derecho Penal Parte Especial 6 ${ }^{\mathrm{a}}$ Ed. Coord. JL González Cussac, Tirant lo Blanch, Valencia, 2019, pág. 590 lo califican de discutible. BaucELls LLAdós, J. «Comentarios al art. 337» Comentarios al Código Penal Parte Especial, Dtores. J. Córdoba Roda/M.García Arán, Marcial Pons, Madrid, 2004, pág. 1469 rechaza la necesidad de intervención del Derecho penal por no apreciar bien jurídico protegido.

26 Prats Canut,J.M.-Maroues Banoue, M. Comentarios al Nuevo Código Penal $3^{\text {a }}$ Ed. Dtor. G. Quintero Olivares, Navarra, 2004, pág. 1769.TorRes FERnÁNDEZ, E. «La reforma del maltrato de animales domésticos del artículo 337 CP», Diario La Ley no 753423 de Diciembre de 2010, pág. 7.

27 Hava García. E. «La protección...» cit. pág. 290. 
como seres vivos con capacidad de sentir emociones y sufrimientos ${ }^{28}$, y al derecho a no ser maltratados ${ }^{29}$.

Una de las consecuencias que lleva reconocer como bien jurídico protegido el bienestar animal es que se pueda apreciar concurso de delitos con el delito de daños cuando el maltrato lo lleva a cabo una persona distinta a su propietario por afectar a dos bienes jurídicos distintos ${ }^{30}$, solución diferente a la mantenida por la SAP de Cuenca 55/2016, de 22 de Marzo que apreció en uno de estos supuestos concurso de leyes.

Desde esta perspectiva, los animales forman parte de la biodiversidad o variedad de organismos vivos como elementos integrantes del medio ambiente, lo que les dota de una autonomía valorativa que justifica el rechazo a su consideración como objeto de propiedad, así como su consecuente y sesgada consideración antropocéntrica que sólo ve en el maltrato la afección a los sentimientos de rechazo de los humanos, si bien, en cumplimiento de los principios de intervención mínima y proporcionalidad, su tutela penal requerirá de una selección de conductas caracterizadas por su gravedad que deberán ser definidas en torno al sufrimiento animal, con un nivel de exigencia cada vez mayor en orden a la regulación de la convivencia entre humanos y animales, y a una respuesta punitiva adecuada.

Esta concepción transformadora de las relaciones de convivencia entre seres humanos y animales ha producido cambios en el ámbito privado pero también en el público, de esta manera en el ámbito público, la relación con los animales ha adquirido una dimensión social con normas que regulan materias tan diversas como la creación de zonas específicas de recreo en los espacios públicos, el acceso a establecimientos abiertos al público, el uso de animales con fines terapéuticos, e incluso campañas que promocionan la adopción de mascotas para erradicar el comercio oneroso... todo ello son muestras de que los intereses de los animales ya son tenidos en cuenta en las reglas de convivencia ciudadana.

Por su parte, en el ámbito de la intimidad familiar el animal se ha integrado en el núcleo familiar y social más cercano a los seres huma-

28 Como señales inequívocas de sufrimiento de los animales se citan los gemidos, vocalizaciones intensivas, resistencias, temblores, convulsiones, otros signos externos de aflicción e incluso algunos sin manifestación externa. Mosterin, J. Animales y ciudadanos, Talasa, Madrid, 1995, pág. 48.

${ }_{29}$ Ríos Corbacho, J.M. «Los animales como posibles sujetos de Derecho Penal». Revista de Derecho penal de la Universidad de Freiburg http://www.unifr.ch/derechopenal/ articulos/a_20080526_86.pdf pág. 12.

30 Baucells Lladós, J. “Comentarios...» 2004, cit. pág. 1474. Cuerda Arnau, M.L. «Maltrato...» 2015, cit. pág.1088. MANZANARES SAMANIEGO, J. L. «El maltrato... « 2018, cit. pág. 43. 
$\operatorname{nos}^{31}$ lo que despierta sentimientos de apego que pueden tener diversos efectos, por ejemplo, que la muerte dolosa del animal genere el reconocimiento de daños y perjuicios en sus propietarios por el daño moral derivado de los afectos que produce su pérdida, SAP de Córdoba 63/2017, de 17 de Febrero, o que se admita que los animales puedan ser utilizados o violentados en el seno de la violencia instrumental para dañar a las personas, SAP de Tarragona 340/2009, de 26 de Diciembre.

En ambos casos, lo que podría parecer una muestra más de cosificación, convierte a los animales en miembros del grupo familiar que despiertan y generan sentimientos, desarrollando un interés directo en salvaguardar su propio bienestar y evitar que sean utilizados para dañar a los intereses personales. En este contexto, es preocupante la utilización de la producción de daños a los animales para doblegar voluntades dentro del ámbito de la violencia ambiental e intimidatoria por su ascendente representación en el ámbito de la violencia intrafamiliar ${ }^{32}$.

\subsection{Las claves de la reforma legislativa}

La protección penal de los animales comenzó en España en 1995 con la introducción del maltrato de animales domésticos como infracción leve contra los intereses generales regulada en el art.632 del Código Penal. Posteriormente sufrió varias modificaciones, todas ellas para ampliar el objeto de protección y las conductas punibles, siendo especialmente relevante que en 2003 (LO 15/2003, de 25 de Noviembre) pasara a ser delito regulándose en el art. 337 del Código Penal y que en 2010 (LO $5 / 2010$, de 22 de Junio) se ampliara el objeto de protección incluyendo también a los animales amansados, y se suprimiera la necesidad de ensañamiento en el maltrato para facilitar su aplicación. Finalmente, en la LO 1/2015, de 30 de Marzo el objeto de protección avanza en su proceso de ampliación, hasta alcanzar prácticamente a todo tipo de animal, salvo los salvajes, reestructurando todo el delito, adoptando un esquema muy similar al del delito de lesiones, e introduciendo novedades relevantes en la penalidad.

Como se puede observar, la evolución se ha producido en un corto espacio de tiempo y ha sido de una gran intensidad, ya que lo que empezó como una falta castigada con pena de multa dirigida a proteger solo a los animales domésticos, ha pasado a ser delito, a proteger a todos los animales, a excepción de los salvajes, y a que la pena impuesta permita el in-

31 Vercher Noguera, A. «Nuevas perspectivas...» cit. 2017, pág. 28. Bernuz Beneitez, $\mathrm{M}^{\mathrm{a}}$.J. «¿Castigos (eficaces) para delitos contra los animales? Repensando la respuesta al maltrato animal» In Dret 1.2020, pág. 394.

32 Bernuz Beneitez, $M^{\mathrm{a}} \mathrm{J}$ «El maltrato animal como violencia doméstica y de género. Un análisis sobre las víctimas», Revista de Victimología n 2, 2015, pág.100. 
greso en prisión. Todo ello es consecuencia de un movimiento imparable tanto a nivel nacional como internacional que, auspiciado por diferentes colectivos que defienden los derechos de los animales, ha ido asumiendo las tesis animalistas que niegan que los animales sean considerados meros instrumentos al servicio de los seres humanos, para admitir la tutela de una serie de derechos reconocidos legalmente.

En este ámbito legislativo destacan por su importancia aquellas normas internacionales que en los últimos años han formulado recomendaciones en orden a mejorar la tutela de los derechos de los animales y que, sin duda, han influido en las últimas reformas penales, y respecto a las normas nacionales, se puede resaltar, de un lado, la trascendencia de las normas de protección animal aprobadas por las Comunidades Autónomas, por su función de frontera de lo punible y, de otro, la propuesta de modificación del Código civil dirigida a poner fin a la ya denostada cosificación legal de los animales.

Entre las normas internacionales que han impulsado la tutela jurídica de los derechos de los animales destaca la Declaración Universal de los Derechos del Animal aprobada por la Liga Internacional de los Derechos del Animal en 1977, en 1978 por la UNESCO y posteriormente por la Asamblea General de Naciones Unidas. En ella, después de reconocer en el Preámbulo que todos los animales poseen derechos, que los hombres cometen graves atentados contra ellos y contra la naturaleza, que el respeto a otras especies es el fundamento de la coexistencia, que el respeto de los hombres a los animales es vinculante al propio respeto entre los hombres y que, a través de la educación, se ha de proporcionar el respeto y afecto a los animales, recoge un catálogo de derechos entre los que destaca por su importancia que el artículo 3 disponga «ningún animal será sometido a malos tratos ni actos crueles».

Dicho catálogo de derechos no pasa de ser una lista de principios programáticos de buen gobierno entre humanos y animales, lo que, al no ser vinculante, resulta insuficiente para abordar todos los actos de maltrato, agresiones y abandono que sufren muchos animales, e incapaz de dar una respuesta clara a todo tipo de conductas pero, al menos, ha servido para generar una mayor sensibilidad social de rechazo al maltrato animal, para inspirar cambios legislativos dirigidos a regular las prácticas y actividades con animales que mejoren su bienestar ${ }^{33}$ y para aumentar las críticas a conductas socialmente toleradas para deleite de los seres humanos pese a los sufrimientos que causan a los animales.

En el ámbito europeo el artículo 13 del Tratado de Funcionamiento de la Unión Europea firmado en Roma en 1957 establece que los anima-

33 Por ejemplo, una nueva ética del consumidor dirigida a coordinar las políticas económicas y sociales con una mayor preocupación por el bienestar animal. E. HavA GARCÍA «La protección del bienestar animal...» cit. pág. 264. 
les son seres sensibles y que su bienestar debe estar presente en las políticas europeas para la protección y el bienestar de los animales, siendo su valor vinculante el que ha propiciado importantes cambios legislativos, si bien más en el ámbito administrativo y civil, que en el penal ${ }^{34}$.

Y por último, el Convenio europeo sobre protección de animales de compañía de 13 de Noviembre de 1987, ratificado por España treinta años después de su aprobación (BOE de 11 de octubre de 2017), destaca las obligaciones derivadas del cuidado de los animales de compañía y la prohibición del sufrimiento innecesario y el abandono.

Pasando al ámbito nacional, se quiere destacar en primer lugar las diversas normas administrativas de protección de los animales por su contribución a la evolución y desarrollo de las normas penales. Esta relación se aprecia en la necesidad de marcar la diferencia entre ilícito administrativo e ilícito penal, ante la posible duplicidad de normas que comparten el objetivo común de proteger a los animales frente al maltrato y el abandono, velando por el cumplimiento del principio ne bis in idem. Además, la interpretación de los términos típicos «injustificadamente» $\mathrm{y}$ «espectáculos no autorizados legalmente» en el actual art.337.1 y 4, respectivamente, va a requerir de la comprobación de la normativa específica correspondiente para poder valorar la presencia de un maltrato prohibido. Finalmente, la delimitación del propio objeto del delito, y su dependencia o no de las normas autonómicas de protección, sin duda ha ocupado buena parte de la discusión de esta conducta delictiva por las dudas del alcance de la intervención penal.

Es especialmente relevante que todas las CCAA se hayan sumado a este movimiento internacional en la defensa de los derechos de los animales, si bien esta pluralidad normativa ha evidenciado sendas diferencias en aspectos conceptuales básicos, como puedan ser las tipologías de los animales objeto de tutela ${ }^{35}$, debido a que en ellas se refleja la diversidad territorial y sus correspondientes niveles de intervención.

Estas diferencias conceptuales de las distintas categorías de animales en la legislación autonómica de protección animal han sido el primer motivo que ha dificultado extrapolarlo para configurar un concepto único y válido para el ámbito penal ${ }^{36}$, abocando al diseño de un concepto propio de animal a efectos penales. Tras importantes oscilaciones en la aplicación jurisprudencial, en la actualidad se ha reducido sustancialmente el interés hermenéutico del concepto de animal como consecuencia de la incesante ampliación del objeto del delito, que ya deja pocas

34 Manzanares Samaniego, J.L. «El maltrato de animales ... cit. pág. 3.

35 . Muñoz Lorente, J. «La protección... « 2007, cit. pág. 19. Hava García. E. «La protección...» 2011, cit. pág. 296. REQuEJo CondE, C. «El delito de maltrato...» 2015, cit. pág. 11.

36 Olmedo de la Calle, E.»Los delitos... «cit . pág. 12. 
dudas sobre las especies que quedan dentro de su ámbito de protección, al haber optado por una protección casi universal con la excepción de los animales salvajes.

En relación a las diversas normas de autorización y regulación de espectáculos públicos, debe tenerse en cuenta que reflejan los diversos usos y tradiciones existentes a lo largo de todo el territorio nacional, lo que se ve inmerso en un profundo proceso de cambio que trata de conciliar el progresivo avance en el rechazo al uso de animales en actividades no necesarias para el ser humano, como sin duda son los espectáculos públicos, y la seña de identidad que despiertan como expresión territorial. Esto puede explicar que si bien las corridas de toros o los circos con animales que afectan a un mayor número de territorios, hayan entrado en un lento retroceso, causa cierta preocupación que otras actividades más localizadas, como puedan ser las peleas de gallos, tengan un fuerte arraigo que dificulte su extinción ${ }^{37}$, o que incluso otras, como los festejos usando animales, se vean cada vez más extendidos.

En este somero repaso de la normativa extrapenal de referencia en la evolución de los derechos de los animales no puede dejar de mencionarse la importancia del tratamiento de los animales en el Código Civil español, y en especial las expectativas que genera la propuesta de reforma para que los animales dejen de ser tratados como objetos. Esta idea de los animales como objeto de propiedad tiene manifestaciones tan diversas como la compensación al propietario por los daños que se produzcan a sus animales, como establece el art. 1902; la responsabilidad de los propietarios por los daños producidos por los animales, como indica el art. 1905 o que, incluso, en relación a la custodia de las mascotas en las disputas conyugales, aunque se basen en el afecto, no se pueda ignorar su naturaleza de objetos de propiedad, todo lo cual abriga la idea de cosificación y dominación sobre el animal.

En la actualidad se va produciendo un cambio progresivo que cuestiona que los animales sigan siendo considerados objetos, y no seres sensibles, siendo paradójico que "al mismo tiempo que la legislación penal ya había empezado a distinguir los daños a los animales domésticos de los daños a las cosas, el Código Civil seguía ignorando que los animales son seres vivos dotados de sensibilidad». Con estas palabras comienza la Exposición de Motivos de la Proposición de Ley de 1 de Marzo de 2019 de reforma del Código Civil, que quedó paralizada por la convocatoria de elecciones generales, y cuyo mayor reto es la voluntad de despojar a los animales del estatuto jurídico de cosas u objetos para reconocerles como «seres vivos dotados de sensibilidad». Con ello no pierden totalmente su sometimiento al

37 Cervelló Donderis, V. «El maltrato de animales en el Código penal español», Revista General de Derecho penal $\mathrm{n}^{\circ} 10,2008$, pág. 22. De esta manera han sido vanos, hasta la fecha, los intentos de prohibirlas en Canarias donde la Ley de protección animal de 1991 las autoriza con condiciones. 
régimen jurídico de los bienes o cosas ${ }^{38}$, ya que se mantiene su relación de propiedad privada de las personas, pero siempre que sea compatible con el respeto al bienestar animal y vetando el maltrato, el abandono y la provocación de la muerte cruel e innecesaria, lo que puede suponer, por ejemplo, que en las crisis matrimoniales la decisión judicial sobre el cuidado de los animales de compañía no dependa solo de la titularidad sobre el mismo, sino que incluso se valore el bienestar animal.

Una consecuencia importante de esta nueva concepción del animal para la interpretación de los tipos delictivos es la relevancia que puede tener el maltrato animal en la violencia de género cuando el animal entra en las disputas conyugales derivadas de procesos de separación o divorcio, así como cuando las desavenencias sobre el cuidado y custodia de los animales desembocan en episodios de violencia ${ }^{39}$. De tal forma, son varias las conexiones establecidas entre maltrato animal y violencia familiar, en general, y violencia de género, en particular ${ }^{40}$, por ejemplo, si se utiliza el maltrato del animal como instrumento de violencia psíquica sobre la mujer o algún miembro de la familia, si el maltrato animal puede ser en sí mismo un instrumento de poder y dominio sobre los miembros de la familia, o si el maltrato de animales puede afectar a los menores de edad que lo presencien ${ }^{41}$. La clarificación por el Código Civil de la situación de las mascotas en los convenios reguladores en caso de separación o divorcio puede desplegar un efecto preventivo y disuasorio de las mencionadas conductas violentas.

\section{Los nuevos contornos del delito de maltrato animal}

La primera ampliación del delito de maltrato de animales desarrollada en 2003, la realizada posteriormente en 2010, y especialmente la recogida en 2015 son un claro ejemplo de que la regulación de estos delitos cada vez se aproxima más a la de los delitos contra las personas ${ }^{42}$,

38 Arribas Atienza, P. «El nuevo tratamiento civil de los animales», Diario La Ley nº136, 9 de febrero de 2018, pág. 5 .

39 En la SAP de Barcelona 353/2018, de 15 de Mayo se reconoce que las desavenencias conyugales que provocaron el episodio violento del agresor hacia su expareja sentimental se iniciaron precisamente por el desacuerdo sobre los días de entrega del perro que tenían en común. La SAP de Barcelona 1044/2006, de 5 de Diciembre vincula las agresiones domésticas sufridas con la agresión a la mascota y la SAP de Tarragona 340/2009, de 26 de Diciembre admite que la discusión de la pareja es lo que llevó al agresor a tirar a la perra por el balcón.

40 Sobre la conexión entre maltrato animal y maltrato interpersonal, DE SANTiAgo FERNÁNDEZ, L. «El maltrato animal desde un punto de vista criminológico» Derecho y cambio social, Año 10, n 33, 2013, pág. 4. KRONHARDT SCHEFFER, G. «Animal abuse: a close realtionship with domestic violence», Derecho Animal, 2019, vol. 10/2, pág. 58.

41 Bernuz Beneitez, $\mathrm{M}^{\mathrm{a}} \mathrm{J}$ «El maltrato animal...» cit. pág. $100 \mathrm{y}$ ss.

42 Requejo Conde, C. «El delito de maltrato...» cit. pág. 1. 
ya que el delito de maltrato animal ha ido adquiriendo progresivamente una estructura similar a la del delito de lesiones, como se ve reflejado en la expresión "por cualquier medio o procedimiento» relativa a los medios comisivos, la modulación de la pena según el resultado obtenido o el sistema de agravantes específicas donde se dan claras coincidencias. Estas similitudes, unidas a la problemática que ciertas conductas delictivas provocan y que dificultan su interpretación y su aplicación práctica, han dado lugar a que el inicial rechazo a estos tipos delictivos haya virado hacia una discusión sobre el encaje de ciertas categorías dogmáticas concebidas para la tutela de los derechos de las personas.

De esta forma, y teniendo en cuenta que el reconocimiento de la tutela penal de los derechos de los animales es posible que exija una revisión conceptual, a continuación se van a seleccionar ciertos elementos típicos cuya interpretación puede requerir algunas particularidades de adaptación en relación a los animales como nuevo objeto de protección penal, lo que sucede en la cualidad de sujeto pasivo, la estructura de la conducta típica, las modalidades comisivas con especial mención de los deberes de cuidado y el sistema de agravaciones.

\section{1. ¿Animal objeto material o sujeto pasivo del delito?}

La regulación del delito de maltrato animal ha conseguido reconocer que los animales ya no pueden ser considerados como meras cosas propiedad de sus dueños por el amplio consenso existente en torno a la idea del bienestar animal como bien jurídico protegido, siendo sin embargo discutible si el titular de este derecho es el propio animal, lo que le convertiría en sujeto pasivo, o es la sociedad, en cuyo caso el animal quedaría como objeto material de la conducta delictiva. Desde la Ilustración se sostiene la idea de que sólo las personas pueden ser sujetos de derechos, lo que da lugar a entender que los animales, al igual que las cosas, deben ser concebidos como meros objetos sobre los que recae la acción delictiva, lo que ocurre es que, al igual que el reconocimiento de la responsabilidad penal de las personas jurídicas ha forzado a adaptar las categorías pensadas inicialmente en exclusividad para personas físicas, cabría preguntarse si también en este caso es posible extender la titularidad del bien jurídico más allá de los seres humanos.

Son varios los argumentos que se utilizan para rechazar su consideración de sujeto pasivo, por ejemplo, que de serlo también deberían ser sujeto activo susceptible de responsabilidad penal, y ello no es posible al carecer de capacidad de actuación responsable, o que no puedan defenderse ni hacer valer sus derechos por la incapacidad de ejercitarlos y de 
mantener relaciones jurídicas ${ }^{43}$, sin embargo, que los animales no puedan ejercitar por sí mismos sus derechos, además de no alcanzar a su titularidad, puede solventarse por la vía de la representación legal ejercida por asociaciones protectoras o por el Ministerio Fiscal ${ }^{44}$. Mantener que los animales disponen de intereses propios al igual que todos los seres vivos se puede deducir de la referencia a su bienestar y dignidad ${ }^{45}$ o de la posibilidad como seres animados de expresar sus sentimientos, algo de gran utilidad para la calificación penal del maltrato sufrido y que permite valorar las atenciones y cuidados necesarios para su recuperación ${ }^{46}$.

Por todo ello, y teniendo en cuenta las evidentes distancias entre los derechos subjetivos de los seres humanos y los de los animales, solo sosteniendo que el bien jurídico del delito de maltrato animal son los sentimientos colectivos de compasión se puede concluir que el sujeto pasivo sea la sociedad quedando el animal como un objeto protegido solo de forma indirecta ${ }^{47}$, lo que queda lejos de las últimas reformas legales caracterizadas por la aproximación de la tutela penal del maltrato animal a la regulación del delito de lesiones, si se tiene en cuenta la ampliación de conductas, las diferencias penológicas en función de los resultados ${ }^{48}$, e incluso, que ya no exija el ensañamiento en la conducta básica, lo que implica que lo relevante es el maltrato innecesario y no un sufrimiento reforzado ${ }^{49}$.

Todo ello, en definitiva, son síntomas de un proceso de transformación en el que los animales al adquirir progresivamente mayor protagonismo, parecen ser algo más que un simple objeto material al reconocerse que son seres sintientes con capacidad de sufrir daños y emociones,

43 Pelayo González-Torre, A. «Sobre los derechos...» 1990, cit. pág. 554. Serrano TÁrragA, M ${ }^{\mathrm{a}}$ D. «El maltrato de animales en el Código Penal» Diario La Ley n6274 14 de Junio de 2005, pág. 4. Muñoz LoRenTE, J. «La protección penal...» 2007, cit. pág. 12-13. Manzanares Samaniego, J. L. «El maltrato de animales...» 2018, cit. pág. 44.

44 Ríos Corbacho, J.M. «Nuevos tiempos... « cit. pág. 21.

45 Vercher Noguera, A. «Nuevas perspectivas...» 2017, cit. pág. 13. Como interés en no sufrir Pelayo González-TorRe, A. «Sobre los derechos...»1990, cit. pág. 554.

46 Con la finalidad de concienciar a la sociedad de la problemática del maltrato animal el Juzgado de lo Penal $n^{\circ} 1$ de Tenerife citó a declarar como testigo a un perro para que el Ministerio Fiscal y el perito veterinario expusieran en su nombre en la vista tanto las lesiones sufridas como sus consecuencias, https://elpais.com/sociedad/2019/05/08/ actualidad/1557313692_014235.html

47 Serrano Tárraga, M Ma D. «El maltrato de...» 2005, cit. pág. 9. Muñoz Lorente, J. «La protección penal...» 2007, cit. pág. 17 así lo entiende al sostener que el animal es el objeto material de delito y la sociedad en su conjunto titular del bien jurídico protegido por el interés de que los animales no sean maltratados.

48 Este era precisamente uno de los impedimentos de la regulación anterior que planteaba Muñoz Lorente, M. «La protección penal...» cit. 2007, cit. pág. 14 y que ha desaparecido tras la reforma de 2015. HAVA GARCía, E. «La protección...» 2001, cit. pág. 282 .

49 Zapico Barbeito, M. "Hacia un nuevo bien jurídico del delito de maltrato de animales domésticos o amansados» Revista de Derecho y proceso penal $\mathrm{n}^{\circ} 25,2011$, pág. 23. 
por ello, si se mantiene que el bien jurídico es el bienestar animal, y teniendo en cuenta que ser sujeto pasivo implica ser titular de derechos subjetivos que no siempre se pueden ejercitar, hay que valorar si la posibilidad de su representación procesal y la evidencia de que los hombres tienen deberes con los animales que no pueden ser extralimitados, son razones suficientemente relevantes para su consideración como sujeto pasivo pese a las dificultades apuntadas ${ }^{50}$.

En todo caso, más allá de su consideración como sujeto pasivo o como objeto material ${ }^{51}$, lo importante es que quede clara la prioridad del interés en defender el bienestar animal como objeto de tutela ${ }^{52}$, ya que la consideración de sujeto pasivo u objeto material depende estrechamente del bien jurídico que se mantenga ${ }^{53}$, pese a ello, seguir calificándolo de objeto material por el rechazo a su condición de sujeto pasivo, no siempre significa seguir cosificándolo si va acompañado de su reconocimiento como bienes jurídicos dignos de protección.

\subsection{Estructura de la conducta típica y modalidades comisivas}

En la actualidad, los delitos recogidos en los arts. 337 y 337 bis del Código penal se puede agrupar en cuatro grupos diferentes:

- Maltrato injustificado de cualquier tipo de animal, salvo que sea salvaje, que le cause lesiones graves o sometimiento a explotación sexual con agravaciones por los medios empleados, los resultados producidos, el ensañamiento o la presencia de menores, art. 337.1 y 2 CP.

- Maltrato injustificado de cualquier tipo de animal, salvo que sea salvaje, que le produzca la muerte, art. $337.3 \mathrm{CP}$.

- Maltrato cruel de animales domésticos o de cualquier animal en espectáculos no autorizados legalmente art. 337.4 CP.

- Abandono en condiciones en las que puedan peligrar la vida o integridad de cualquier animal, salvo que sea salvaje, art. 337 bis $\mathrm{CP}$.

Estas cuatro categorías penales se pueden agrupar en tres situaciones que distinguen entre delitos de resultado, delitos de mera actividad y delitos de peligro:

50 Zapico Barbeito, M. «Hacia un nuevo...» 2011, cit. pág. 19. Ríos Corbacho, J.M. «Nuevos tiempos...«2016, cit. pág. 28.

51 Algo sin demasiada relevancia más allá de las categorías dogmáticas como señala Hava GaRcía, E. «La protección.... cit. pág. 291.

52 Hava García, E. «La protección...» cit. págs. 283, 392.

53 Zapico Barbeito, M. «Hacia un nuevo...» cit. pág. 15. 
- Delito de resultado: Maltrato injustificado que cause lesiones graves o la muerte del animal: se trata de un delito de resultado con modalidad de conducta abierta. La referencia legal del sometimiento a explotación sexual junto a la causación de lesiones graves es debida a la necesidad en ambas de un maltrato injustificado.

- Delito de mera actividad: Delito de maltrato de animales domésticos o no domésticos, pero en este último caso en espectáculos no autorizados legalmente.

- Delito de peligro: Abandono de cualquier animal no salvaje que pueda poner en peligro la vida o integridad del animal.

Pese a la evidente amplitud que han sufrido los tipos penales, en esta última reforma penal sigue habiendo diversas restricciones que pueden limitar su aplicación, de esta forma de una primera lectura podría excluirse el castigo de la muerte o las lesiones si no ha habido previo maltrato, también se da a entender que caben maltratos justificados, y además se condiciona la punición del abandono a la creación de un peligro; todo ello es producto de una regulación que, aun siendo expansiva, viene limitada por el carácter fragmentario y subsidiario del Derecho penal vinculado a los criterios de necesidad de tutela y proporcionalidad, lo que provoca una regulación a veces confusa e incapaz de superar los reiterados problemas de inaplicación que se arrastran desde el inicio de estas conductas delictivas.

En los delitos de maltrato animal hay que diferenciar en primer lugar los actos de maltrato que no causen ulterior resultado de aquellos otros que provoquen lesiones que menoscaben gravemente la salud o la muerte, ya que en estos últimos la conducta del maltrato deberá ir unida necesariamente a la causación de un resultado ${ }^{54}$. A continuación se van a analizar aquellos elementos típicos que han sido revisados legalmente para observar cómo han afectado a la estructura global del tipo delictivo y cómo pueden ayudar a esclarecer su ámbito de aplicación.

\section{a) Maltrato con resultado de lesiones graves o muerte}

El núcleo de este delito es el maltrato injustificado que produce en el animal lesiones graves en el tipo básico, o su muerte en el tipo cualificado. En el primer caso es novedosa la similitud de su redacción con el delito de lesiones, ya que al compartir estructura, medios comisivos y agravaciones se refuerza la idea de que en este precepto se protege a los animales de forma casi general sin limitarlo a aquellos que mantienen especial vínculo con los humanos, como puedan ser los domésticos o amansados. Además se mejora la proporcionalidad ${ }^{55}$, habida cuenta de

\footnotetext{
54 En el mismo sentido Cuerda Arnau. M. ${ }^{\text {a }}$ L. «Maltrato... » cit. pág. 1082.

55 Ríos Corbacho, J.M. «Nuevos tiempos...» cit. pág. 22.
} 
la nueva diferencia penológica entre el resultado lesiones y el resultado muerte, lo que contribuye a consolidar la idea de un bien jurídico protegido autónomo y no dependiente de los sentimientos de las personas.

El presupuesto previo del maltrato es determinante para la realización del delito siendo necesario adecuarlo a las necesidades y particularidades de los animales ${ }^{56}$, por ello tal término no debería confundirse con las faltas de cuidado que dejan a los animales en pésimas condiciones de salubridad e higiene, indicadoras de una falta de sensibilidad con los mismos, o con los esfuerzos ligados a la condición de animal como algunas prácticas de carga, sino vincularlo a aquellas conductas que, mediante maltrato injustificado, produzcan lesiones graves, algo que los Tribunales deberían esforzarse en definir ${ }^{57}$.

En relación a los resultados no se añade nada nuevo en la reforma que permita concretar el espacio del maltrato que produce lesiones que menoscaben gravemente la salud del animal, sin embargo, el hecho de que se haya incluido como tipo agravado la producción de lesiones especialmente graves por los resultados producidos (pérdida o inutilidad de un sentido, órgano o miembro principal) puede servir de ayuda para reservar el tipo básico para el resto de lesiones graves. Para ello se deberá tener en cuenta que caben tanto los daños físicos como los psíquicos, por la referencia a la salud en general, y que deba necesitarse objetivamente, además de una primera asistencia facultativa, tratamiento veterinario o quirúrgico.

Hay que tener en cuenta que las lesiones de los animales son específicas, no coincidentes con las de los humanos, lo que exige que sean determinadas en informes de profesionales titulados en Veterinaria que dictaminen el sufrimiento del animal, la naturaleza de las lesiones y las consecuencias para su salud con criterios veterinarios ${ }^{58}$. En este sentido, la prueba pericial practicada por estos profesionales es imprescindible para informar del estado físico y psíquico del animal con el fin de poder valorar posibles patologías, sin que sea suficiente ni la mera experiencia del juzgador, ni los tratamientos decididos por los trabajadores de los centros de acogida de animales que carezcan de la titulación correspondiente, por mucho que se reconozca su meritoria actividad con los animales, como recuerda la SAP de Madrid 161/2018, de 7 de Marzo. Cues-

56 El carácter de injustificado es precisamente el que orienta esta dirección CuERDA ARnAU, M ${ }^{\mathrm{a}}$ L. «Maltrato...» cit. pág. 1082.

57 Fernández Álvarez, A. "Protocolo clínico de identificación de maltrato animal» Revista general de derecho animal y estudios interdisciplinares de bienestar animal 0 (2017) pág. 16 y ss. realiza una clasificación de posibles daños para la salud de los animales derivados de acciones humanas no accidentales que le lleva a diferenciar los signos externos de maltrato leve y grave, págs. 40-43.

58 LockwOod, R. Touroo, R.Olin, J.Dolan, E. «The influence of evidence on animal cruelty prosecution an case outcomes: results of a survey», Journal of forensic sciences Noviembre 2019, 64 (6), pág.1688. 
tión diferente es que tras este informe pericial, el órgano judicial deba concretar el alcance de las lesiones derivadas del maltrato, al tratarse de un término abierto que encontrará su límite en el tipo atenuado o en la infracción administrativa ${ }^{59}$.

La referencia a que el maltrato pueda tener lugar por cualquier medio o procedimiento permite admitir tanto la modalidad de conducta activa como la omisiva. El maltrato podrá de esta forma responder a una conducta activa, como golpear al animal, u omisiva, como dejar de alimentar o prestarle los cuidados necesarios, lo que debido a su cualidad de delito de resultado dará lugar a la comisión por omisión, siempre que el responsable sea garante como poseedor o cuidador del animal y se produzcan lesiones graves, o en el caso del tipo cualificado, la muerte ${ }^{60}$.

Otra consecuencia de la mayor relevancia de la vida e integridad de los animales es que se refiera a conductas de maltrato de «un animal» en singular, lo que permite afirmar que si se produce el maltrato sobre varios animales se tratará de un concurso real de delitos por ser varios los bienes jurídicos afectados dada la individualidad del bienestar de cada uno de ellos, lo que es aceptado mayoritariamente ${ }^{61}$.

Cuestión diferente es la admisión de delito continuado cuando diversos actos de maltrato recaigan sobre un mismo animal y se desarrollen en ejecución de un plan preconcebido o aprovechando idéntica ocasión. En este sentido, y descartado el caso de unidad natural de acción que dé lugar a un solo delito, gran parte de la doctrina admite el delito continuado por entender que el maltrato animal no entra dentro de la excepcionalidad del art. 74.3 CP relativa a los bienes eminentemente personales, o que de serlo, entrarían en la excepción de delitos contra el honor lo que, de inicio, y partiendo de la base de que el bienestar animal no es en rigor un bien personal, choca con el paulatino reconocimiento de los animales como objetos de tutela en su calidad de seres sintientes. Ello puede llevar a aconsejar no apreciar la continuidad delictiva para no distanciarse del nivel de protección de la vida y salud de los animales alcanzado especialmente tras la reforma de 2015 y apartarse, a su vez, del tratamiento dado a los bienes patrimoniales ${ }^{62}$.

En relación a la permanencia de la expresión maltrato injustificado además del sentido ya apuntado que excluye del tipo aquellas prácticas

59 Cuerda ARnAU, $\mathrm{M}^{\mathrm{a}}$ L. «Maltrato...» cit. pág. 1083.

60 Reouejo Conde, C. La protección penal de la fauna. Especial consideración del maltrato de animales, Comares, Granada, 2010, pág. 47. Disponible en https://es.slideshare. net/margyed/requejo-capitulolibroelmaltratodeanimales.

61 ReQuejo Conde, C. «El delito de maltrato...» cit. pág. 15.

62 A favor de apreciar delito continuado ReQuejo Conde, C. La protección penal...2010, cit. pág. 61, Cuerda ARnaU, Mª.L. «Maltrato...» 2015, cit. pág. 1088, Olmedo DE La CALle, E. Los delitos... 2017, cit. pág. 243. En contra Manzanares Samaniego, J.L.» El maltrato de animales...»2018, cit. pág. 46. 
unidas a la condición de animal o a las causas de justificación generales ${ }^{63}$, algo por otra parte innecesario en sede de tipicidad ${ }^{64}$, se extiende a situaciones autorizadas específicamente en el ámbito administrativo tan dispares como la alimentación, la experimentación científica, o los espectáculos públicos derivados de tradiciones o costumbres populares. Su lectura desde el principio de ofensividad debe apuntar a entender que la mera falta de autorización administrativa no sea por sí misma lo que conduzca al delito, si no va unida a la causación de lesiones que menoscaben gravemente la salud.

Una de las novedades de la reforma es la creación de un subtipo agravado en virtud del cual el maltrato injustificado cause la muerte del animal lo que da lugar a una pena de prisión de seis meses a dieciocho años e inhabilitación de dos a cuatro años. Con ello se introduce una agravación del tipo básico por el resultado producido, lo que significa que ha de exigirse una situación de maltrato injustificado que en este caso produzca la muerte, es decir, tan necesario es que se trate de un maltrato injustificado como que se produzca la muerte, lo que da lugar a dos consecuencias: no será necesario que haya prolongación innecesaria del sufrimiento por la no exigencia de crueldad o ensañamiento, pero de haberla no influirá en la penalidad ya que la agravación prevista para ello se refiere solo al tipo básico, no al cualificado por la muerte.

Es indiferente que la muerte sea consecuencia de una conducta activa, como golpear, u omisiva, como descuidar las atenciones y cuidados básicos de animal, por eso la muerte por inanición queda dentro de este supuesto, y no del correspondiente al delito de abandono ${ }^{65}$, siempre que se derive de la falta de los deberes elementales de alimentación y cuidados sanitarios. Ejemplos de ello pueden ser la sentencia del Juzgado de lo Penal no 2 de Palma de Mallorca 208/2015, de 28 de Mayo que condenó por maltrato animal en comisión por omisión al propietario de un perro que desatendió totalmente sus cuidados, provocándole una severa desnutrición y grave deficiencia sensomotora hasta el punto de producirle la muerte, la sentencia del Juzgado de lo Penal no 1 de Santander 338/2014, de 28 de Octubre por la muerte por inanición derivada de la falta más

63 SAP de Álava 247/2017, de 13 de Septiembre plantea como estado de necesidad las lesiones graves producidas por los golpes que un pastor propinó a una perra que molestaba a las ovejas del rebaño que cuidaba por entender que se trató de un acto necesario para evitar un perjuicio y además justificado porque el mal causado no fue mayor que el que se quería evitar.

64 Torres Fernández, E. «La reforma...» 2010, cit. pág. 6. Blanco Cordero, I. «Art. 337» en Comentarios prácticos al Código penal Tomo IV Dtor. Gómez Tomillo, Aranzadi, Cizur menor, 2015 pág.181. Cuerda ARnAU, Mª.L. «Maltrato...» 2015, cit. pág. 1083.

65 Cuerda Arnau, Ma ${ }^{a}$.L. «Maltrato...» 2015, cit. pág. 1084. Durán Seco, I. «El maltrato y abandono de animales desde el punto de vista del Derecho penal (L.O. 1/2015 de 30 de Marzo)» Libro-Homenaje a Claus Roxin por su nombramiento Doctor h.c. por la Universidad Inca Garcilaso de la Vega, de Dtor. D.M Luzón Peña Lima 2018, pág. 621. 
absoluta de cuidados de los propietarios de un animal que omitieron los más elementales deberes de alimentación y cuidados sanitarios ${ }^{66} \mathrm{o}$ la SAP de Almería 16/2018, de 18 de Enero donde se condenó al responsable de una granja de lechones que no impidió, como garante, que unos terceros los mataran cruelmente.

En todas estas conductas al tratarse de un tipo de resultado la acción es el maltrato y el resultado la muerte, pero han de estar unidas por una relación de causalidad sin importar si la muerte es inmediata o después de un periodo de tiempo, siempre que sea consecuencia del maltrato. Por esa razón, si se produce la muerte por otros actos, o se maltrata pero la muerte se produce por otra causa (enfermedad, asistencia errónea...), se estaría fuera de este tipo ya que la muerte deben ser consecuencia del maltrato ${ }^{67}$. Del mismo modo, al admitir como tipo de resultado las formas imperfectas, la acción dirigida a matar a un animal sin conseguirlo por causas ajenas a la voluntad del sujeto, merecen la calificación de tentativa, vgr. si el animal es atendido y se logra salvar su vida, o no se producen las lesiones.

Las conductas omisivas que producen un resultado de muerte deben distinguirse de las de mero abandono, residiendo la diferencia en que en la comisión por omisión se produce la muerte como consecuencia del maltrato por quien, al ser garante del animal, debe evitar el resultado, mientras que en el abandono sólo se pone en peligro su vida o integridad, es decir, en el primer delito se exige resultado material, mientras que el delito de abandono es una figura de mera actividad (inactividad) en cuanto a la conducta y de peligro para el bien jurídico. La SAP de Madrid 682/2018, de 29 de Noviembre descarta el mero abandono, calificando de maltrato, al abandono de un perro al que se le provocó lesiones que, de no haber sido asistido, le hubieran podido producir la muerte.

\section{b) El maltrato con sometimiento a explotación sexual.}

Esta novedosa conducta se ha querido plantear como la tipificación de la zoofilia en el Código penal, si bien la redacción final dada por el legislador dista mucho de esta conclusión, ya que tanto el término explotación como su dependencia del maltrato parecen aproximarle más a una modalidad de maltrato consistente en la utilización sexual del animal.

No queda muy claro que el legislador limite el maltrato a los casos de lesiones graves y la muerte o lo extienda también a la explotación sexual, ya que hay autores que defienden que esta última y novedosa conducta vaya desvinculada de las anteriores por tratarse de una conducta meramente sexual. Los tiempos verbales "causándole y sometiéndole» sin embargo parecen indicar que la explotación sexual deba ir vinculada al

\footnotetext{
66 Comentada por S. Pérez Elicegui en Revista Derecho animal Abril 2014.

67 Manzanares Samaniego. J.L. «El maltrato de animales...»cit. págs. 23-24.
} 
maltrato ${ }^{68}$, por tanto no parece referirse a la comisión de cualquier acto sexual con animales, lo que por otro lado es dudoso que pueda quedar dentro de la tutela penal ${ }^{69}$.

Como son varios los países que han incluido la zoofilia como conducta delictiva, como es el caso de Suecia, Alemania, Holanda o Méjico, es previsible que la evolución de los derechos de los animales vaya en esta dirección, lo que debería requerir, en su caso, que no se apoye en cuestiones éticas que rechacen conductas consideradas moralmente depravadas desde una visión nuevamente antropocéntrica, sino en la consideración de que las prácticas sexuales con animales son abusivas siempre que se vinculan a la existencia de maltrato o sufrimiento del animal para que quede garantizado que afectan al bienestar animal, y no a la moral social.

Del mismo modo tampoco resulta adecuado emplear el término «explotación» que indica comercio o difusión cuando el sentido del delito parece ser la instrumentalización del acto sexual con el animal como una forma de maltrato injustificado, y no que ello tenga que ser difundido o comercializado, ya que cabe realizarlo en el ámbito privado. Dicha limitación, por tanto, queda lejos de las pretensiones de la enmienda que dio lugar a su inclusión más cercana a castigar la zoofilia ${ }^{70}$, algo no sólo rechazable en términos de ofensividad, sino de imposible interpretación con la redacción aprobada ${ }^{71}$.

c) Maltrato de animales sin resultado

El tipo regulado en el art. 337.4 se califica en ocasiones de subsidiario y atenuado, pero más bien es un tipo autónomo y residual ${ }^{72}$ de mera actividad, ya que se refiere a cualquier maltrato cruel a animales domésticos no incluido en ninguno de los tipos anteriores o a cualquier otro producido en espectáculos públicos no autorizados legalmente, de esta manera, se trata de un maltrato cruel sin necesidad de ulterior resultado en el que, como delito leve, se castiga con pena de multa e inhabilitación potestativa.

La redacción actual mantiene intactos los problemas de interpretación que se daban anteriormente cuando se trataba de una falta, como son el rechazo que produce admitir que pueda haber maltratos no crueles, o la distinción entre el maltrato a animales domésticos y el que se

68 Ríos Corbacho, J.M. «Nuevos tiempos... «cit. pág. 30.

69 Muñoz Conde, F. Derecho Penal...2017, cit. pág. 531 entiende que no se puede sostener que la zoofilia quede dentro del Derecho Penal, mientras que MARQuÉs BLANQué, M. «Art. 337...» 2017, cit. pág. 873 considera que se tipifica cualquier práctica sexual animal, incluida la zoofilia.

70 Jiménez López, I. Violencia sexual contra animales. Universidad Autónoma de Barcelona, Barcelona 2019.

71 Cuerda Arnau. M ${ }^{\mathrm{a}}$ L.«Maltrato....» 2015, cit. pág. 1084, Manzanares Samaniego, J.L. «El maltrato de animales...» 2018, cit. pág. 33.

72 Manzanares Samaniego, J.L. «El maltrato de animales...» cit. pág. 30. 
produce al resto de animales siempre que no sea en espectáculos públicos no autorizados, que tantas opiniones contradictorias ha provocado.

La confusión se basa en la duda del alcance de la prohibición: ¿se castiga el maltrato cruel de todo tipo de animales, sean domésticos o no, pero solamente cuando se lleven a cabo en espectáculos públicos no autorizados legalmente? o ¿se castiga el maltrato cruel de animales domésticos en todo caso y el maltrato cruel del resto de animales solamente si se produce en espectáculos públicos no autorizados legalmente? La diferencia entre animales domésticos y el resto de animales no pueda significar que el maltrato cruel de un animal doméstico en un espectáculo público no autorizado quede impune, sino que la regla general es que estos maltratos sean en todo caso punibles y, por tanto, también si se realizan en espectáculos públicos, y que en el caso del resto de animales la punición se limite a que el maltrato se lleve a cabo en espectáculos públicos no autorizados, lo que sitúa la prohibición a dos niveles: uno amplio para los animales domésticos y otro más restrictivo para el resto de animales.

Parece con ello que el sentido es remarcar que el maltrato que no produzca lesiones graves solo se castiga si recae en animales domésticos, con independencia del lugar donde se realicen los hechos, y que el maltrato de cualquier tipo de animal realizado en espectáculo público no autorizado es punible, lo que parece ir dirigido a perseguir aquellos espectáculos públicos clandestinos donde se producen sufrimientos a los animales ${ }^{73}$.

Esta aclaración nos permite concluir:

- El maltrato cruel a animales domésticos se castiga en todo caso, con independencia de que se produzca en público, en privado o dentro o fuera de espectáculos. En este caso se trataría de un tipo subsidiario que mantiene la diferencia de los animales domésticos con el resto y se dirige a castigar el maltrato cruel siempre que no produzca lesiones graves.

- En relación al maltrato cruel a cualquier animal en un espectáculo público no autorizado es una alusión a aquellos espectáculos no autorizados precisamente porque suponen un maltrato a los animales ${ }^{74}$, ya que la mera falta de autorización no cumple por sí misma el requisito típico de maltrato ${ }^{75}$.

73 Cervelló Donderis, V. «El maltrato de animales...«cit. págs. 20 y 23.

74 Como tal se podrían incluir las peleas de perros o gallos que se realizan con ánimo de lucro y a sabiendas de que el objetivo es producir lesiones o la muerte del animal, Magaldi Paternostro, M.J. Art. 632 Comentarios al Código Penal Parte Especial. Dtores. J. Córdoba Roda/M.García Arán, Marcial Pons, Madrid, 2004, pág. 2775.

75 Requejo Conde, C. «El delito de maltrato...» cit. pág. 23. 
De esta manera, si la referencia a los espectáculos públicos no puede dejar en manos de la autorización administrativa la línea divisoria entre infracción administrativa e ilícito penal, ni puede entenderse como un mero incumplimiento formal, solo sirve para distorsionar y alentar diferencias de trato legislativo ante situaciones de sufrimiento animal envueltas bajo el amparo de tradiciones y expresiones culturales ${ }^{76}$.

d) Abandono de animales como delito de peligro

También en este caso se ha transformado la falta de abandono en delito leve, pero con dos limitaciones, en primer lugar, se entiende que se refiere a animales domésticos y amansados, no sólo domésticos como anteriormente, pese a que la referencia al apartado primero parece ser a todos los recogidos en el mismo y no solo a los de la letra a) y, en segundo lugar que el abandono sea en condiciones que "puedan» poner en peligro la vida o integridad del animal, es decir, que exista un riesgo grave, pero sin necesidad de producirse la muerte o lesiones para la consumación del delito.

La clave de esta figura delictiva es el nivel de peligro exigido ya que si se trata de peligro concreto ${ }^{77}$, deberá acreditarse la situación efectiva de peligro grave en la que se ha encontrado el animal, mientras que si se trata de peligro abstracto ${ }^{78}$, habrá de realizarse un juicio de probabilidad de los posibles resultados; decantarse por el primero de ellos puede servir para diferenciarlo de las conductas de mero abandono constitutivas de infracción administrativa que siempre conllevan un cierto riesgo, exigiendo en este caso la necesidad de una situación objetiva de peligro para la vida o integridad del animal, para lo cual se valorará si el abandono se ha hecho en condiciones que supongan un riesgo teniendo en cuenta datos objetivos como son el lugar del abandono, la edad del animal, la posibilidad o no de cercanía o ayuda, pero también datos subjetivos como los relativos a las condiciones de salud individuales de cada animal.

Esto sitúa el abandono en tres niveles distintos de protección:

a) abandono sin peligro para el animal, lo que da lugar a una infracción administrativa recogida en el art. 37 n 16 de la LO 4/2015, de 30 de Marzo de Seguridad ciudadana que sanciona el abandono de animales domésticos en condiciones en que pueda peligrar

76 Requejo Conde, C. «El delito de maltrato...» cit. pág. 22.

77 Jabato Martín, A. «Art. 337 bis» Comentarios prácticos al Código penal Tomo IV, Dtor. Gómez Tomillo, Aranzadi, Cizur menor, 2015 pág. 193 y Olmedo de LA CALle, E. Los delitos... 2017, cit. pág. 307. SAP de Asturias 296/2018, de 2 de Julio en el mismo sentido.

78 SERRANo TÁrRAGA, $M^{\mathrm{a} D}$ «El maltrato de...»2005, cit. pág. 11 y ManZanARES SAMANIEGO, J.L.»El maltrato de animales... 2018, cit. pág. 39. En el mismo sentido SAP de A Coruña 244/2017, de 29 de Diciembre. 
su vida, lo que supone un riesgo leve o menos grave respecto a los otros niveles de intervención que exigen un riesgo grave ${ }^{79}$.

b) abandono que coloca en peligro grave la vida o integridad del animal, lo que resulta constitutivo de delito de abandono del art. 337 bis objeto de este comentario.

c) abandono que produce la muerte o lesiones graves del animal propio de un delito de maltrato animal del art. 337 en comisión por omisión (siempre que el abandono sea considerado maltrato injustificado) ${ }^{80}$.

Se trata en este caso, por tanto, de un delito de mera actividad, donde el abandono entendido como una situación de desamparo admite tanto la modalidad activa, que es propiamente dejar abandonado o desamparado a un animal, como la omisiva ${ }^{81}$, consistente en no cumplir con los cuidados mínimos o básicos asociados a la propiedad o custodia de un animal, lo que permite que el sujeto activo sea la persona encargada de sus cuidados, aunque no sea su propietario ${ }^{82}$, y requiere delimitar cuáles son los deberes de los humanos respecto al cuidado de los animales.

La sentencia del Juzgado $\mathrm{n}^{\circ} 1$ de lo Penal de Pamplona/Iruña 121/2018, de 12 de Enero y la SAP de A Coruña 244/2017, de 29 de Diciembre inciden en los elementos básicos de esta figura delictiva como son que la falta de cuidados a los animales produzca desamparo, sin ser necesario que se produzca un resultado lesivo, que sea suficiente con que se realice a título de dolo eventual, o que pueda ser sujeto activo el poseedor y no sólo el propietario, a lo que habría que añadir que se materialice en un peligro grave para la vida o la salud, ya que de lo contrario no estaríamos ante esta figura delictiva. Ejemplo de ello sería el grave riesgo que se produjo para la vida de un perro cuyo dueño dejó en un coche durante dos horas al sol en el mes de Julio, describiendo los signos de fatiga y desnutrición que le produjeron, sentencia 9.2.2017 del Juzgado Instrucción $\mathrm{n}^{\circ} 1$ de Tarragona, y de lo contrario, la SAP de Valencia 602/2018, de 16 de Noviembre que absolvió por el abandono de un perro en la vía pública al no indicarse el peligro que generó tal abandono, lo que recuerda la necesidad de determinar el alcance del peligro provocado con el fin de evitar la absolución por no haberse practicado pruebas periciales veterinarias, como recuerda la SAP de Álava 148/2019, de 7 de Noviembre.

79 Blanco CoRdero, I. «Art. 337»...cit. pág. 190.

80 Cuerda Arnau, M.L. «Maltrato...» cit. 2015, pág. 1089. Requejo Conde, C. «El delito de maltrato...» cit. 2015, pág. 26.

81 Martínez Buján, C. Derecho Penal Parte Especial... 6 ${ }^{\mathrm{a} E d}$, cit. Tirant lo Blanch, Valencia, 2019, pág. 591 lo considera delito de omisión y de resultado concreto.

82 Manzanares Samaniego, J.L. «El maltrato de animales ... cit. pág..38. 
Es evidente que el legislador ha sido sensible a un problema social estructural cada vez más alarmante que ha dado lugar a campañas de publicidad y sensibilidad dirigidas no solo a evitar el abandono de animales, sino también a fomentar su adopción, lo que es una muestra más de la transformación del estatus de los animales ya que, además de protegerlos frente al abandono, se insta a reducir su comercialización y que sean las personas y no las instituciones las que se ocupen de sus cuidados. No obstante, para justificar el principio de mínima intervención no puede recurrirse a esta figura para abordar la situación de desamparo y desatención de cuidados de muchos animales por parte de sus cuidadores, sino para las conductas que ponen en peligro la vida o salud de los mismos, por ello aludir a que se trata de conductas incívicas no debe llevar a confundir el linde con las infracciones administrativas.

\subsection{Sistema de agravaciones}

La inclusión en el art. 337.2 CP de un listado de agravantes específicas casi idéntico al recogido en los delitos de lesiones es uno de los ejemplos más visibles de la aproximación legal de la regulación de los delitos de maltrato animal a los delitos contra las personas, pese a lo cual resulta llamativo e incongruente que solo se puedan aplicar al maltrato que causa lesiones graves o sometimiento a explotación sexual ${ }^{83}$, pero no al que causa la muerte, por la limitación que hace el precepto al apartado anterior que puede ser debida, o bien a un gesto diferenciador de los delitos contra las personas, o bien a un simple olvido del legislador.

Las agravaciones recogidas son las siguientes:

Utilización de armas, instrumentos, objetos, medios, métodos o formas concretamente peligrosas para la vida del animal. Es una agravación idéntica a la del delito de lesiones, salvo que se refiere a poner en peligro la vida del animal, y no su salud física o psíquica como ocurre con las personas, con lo cual se trata de lesiones graves producidas con la utilización de armas o instrumentos que ponen en concreto peligro la vida del animal. Hay abundante jurisprudencia que destaca el uso de objetos potencialmente peligrosos tales como palos, pistolas de balines, piedras... cuya concreta potencialidad de hacer daño a la vida del animal hace necesario que el sujeto activo conozca la peligrosidad objetiva del medio utilizado ${ }^{84}$.

Ensañamiento: Se suprimió en 2010 para facilitar el castigo como delito del maltrato animal, puesto que su exigencia para la aplicación

83 Blanco Cordero, I. «Art. 337...» 2015, cit. pág. 183. Requejo Conde, C. «El delito de maltrato...»2015, cit. pág. 19

84 Muñoz Conde, F. Derecho Penal ... cit. pág. 100. 
del tipo básico obligaba en su ausencia a castigar como falta. En 2015 se incorpora de nuevo, pero en este caso como tipo agravado, lo que supone que da paso a la imposición de penas más elevadas. En el delito de lesiones la agravación incluye el ensañamiento o la alevosía, pero aquí solo contempla el ensañamiento, si bien se consolida la idea de que el concepto de ensañamiento es único en el Código Penal ${ }^{85}$, por tanto se interpretará conforme a la definición del art. 22.5 CP que lo describe como el aumento deliberado e inhumano del sufrimiento de la víctima que causa padecimientos innecesarios para la ejecución del delito.

El carácter de inhumano en este sentido no sería tanto relativo al dolor del animal, sino al agresor y a su modo de actuar, por la producción de un plus de sufrimiento deliberado e innecesario ${ }^{86}$. Entendido como crueldad innecesaria en la realización de la conducta típica son dos los elementos que lo definen según la jurisprudencia del Tribunal Supremo: un elemento objetivo consistente en que se hayan producido males objetivamente no necesarios para el resultado que provoquen un aumento del sufrimiento, y un elemento subjetivo en virtud del cual el autor realice sus actos asumiendo que aumentan el sufrimiento, precisamente por ser innecesarios. Este último elemento es el que más problemas de interpretación ha provocado ya que las dificultades probatorias, su confusión con la premeditación, o la necesidad de ir unido a actos positivos, y no sólo omisivos, han dificultado mucho su aplicación ${ }^{87}$. En todo caso, su nueva ubicación como agravante debe ir unida a una aplicación excepcional y selectiva en la que el sufrimiento innecesario aporte un plus de lesividad al maltrato. En este sentido, si bien refiriéndose a la redacción anterior puesto que los hechos datan de 2008, la SAP de Santa Cruz de Tenerife 111/2016, de 10 de Marzo consideró que había ensañamiento en la brutalidad de la muerte a golpes de unos cachorros puesto que además de aumentar su dolor de manera innecesaria se prolongó su sufrimiento, la SAP de Castellón de 2 de Febrero de 2006 lo apreció por colgar a un perro de una rama de olivo valiéndose de una soga que rodeaba su cuello hasta producirle la muerte y la SAP de Cádiz 241/2018, de 29 de Junio por la práctica de la eutanasia suministrando un medicamento que provocaba una muerte agónica y cruel por el mero propósito de ahorro económico y energético.

Causar en el animal la pérdida o inutilización de un sentido, órgano o miembro principal. Es más amplia la agravación en el caso de las lesiones personales al alcanzar además a la impotencia, esterilidad, grave defor-

85 Marqués Blanqué, M. «art. 337» Comentario a la reforma penal de 2015, Dtor. G. Quintero Olivares, Aranzadi, Pamplona, 2015, pág. 667.

86 MuÑoz Lorente, J. «La protección penal...» 2007, cit. pág. 26. TorRes Fernández, E. «La reforma...» 2010, cit. pág. 5. Olmedo DE LA CALLE, E. Los delitos...2017, cit. pág. 277.

87 Requejo Conde, C. «El delito de maltrato...» cit. pág. 17. 
midad o grave enfermedad somática o psíquica, por eso, la agravación establecida para los animales se limita a sentidos, miembros u órganos principales, pero siempre que se haya producido una pérdida o inutilización de los mismos, sin ser suficiente la meras deformidad que no provoque su falta de funcionalidad. Dada la similitud con el delito de lesiones no hay razones para no extender al mismo la interpretación referida a los conceptos referidos a sentidos, órganos o miembros principales así como pérdida o inutilización, por ejemplo, la pérdida de visión, la cojera... ${ }^{88}$

Comisión de los hechos en presencia de un menor de edad: en este caso la nueva agravación consistente en ejecutar los hechos en presencia de menores no está contemplada entre las agravaciones de delitos de lesiones genéricas, sino solo en los delitos de violencia de género y maltrato doméstico con similar redacción a la recogida en el maltrato ocasional regulado en el art. 153.3, es decir, amenazas y coacciones reguladas en los arts.171.5 y 172.2 y violencia doméstica habitual regulada en el art.173.2. En todos ellos se justifica la agravación en la mayor vulnerabilidad de los menores de edad y el impacto emocional que les puede producir presenciar la violencia inherente a los actos de maltrato animal, así como la influencia que ello pueda producir en el desarrollo de su formación. Para mantener el principio de proporcionalidad y de intervención mínima debe descartarse su aplicación automática, limitándola a aquellos supuestos en los que el responsable de los hechos conozca tanto que se presencian los actos como que se trata de menores de edad y todo ello, al menos, a título de dolo eventual. Hasta la fecha se ha aplicado muy escasamente, siendo uno de los supuestos la SAP de Badajoz 102/2018, de 13 de Junio, por la muerte y lesiones de gravedad provocadas a dos perros que fueron arrojados a un foso y apedreados por un adulto acompañado de un menor de edad.

\section{Consecuencias prácticas de la evolución en la interpretación de los elementos típicos}

\subsection{Ampliación del ámbito de aplicación}

De forma paralela a los cambios legislativos anteriormente analizados, el maltrato animal ha sufrido una progresiva evolución en la aplicación práctica por los órganos jurisdiccionales, que además de ser la consecuencia natural de una nueva regulación, también se percibe como una mayor sensibilidad a los cambios sociales.

De esta manera, si bien en el pasado los actos de maltrato animal eran considerados como delito de daños por la consideración de los ani-

88 Ríos Corbacho, J.M. «Nuevos tiempos...» cit. pág. 35. 
males como objetos, en la actualidad, la protección del bienestar animal ha pasado a ser un objeto de protección propio que prioriza el sufrimiento al que se ven sometidos los animales como seres sintientes con capacidad de sufrir dolor y emociones.

Uno de los primeros aspectos a destacar en esta evolución es la delimitación de los animales objeto de protección penal, ya que desde una inicial tutela limitada a los animales domésticos o de compañía, se ha extendido a los animales de granja, a los amansados y a todos aquellos que vivan bajo el control humano, dejando fuera solo a los animales que vivan en estado salvaje, lo que queda muy lejos de aquellas sentencias absolutorias que se basaban en la no cohabitación con el animal, al bastar actualmente con probar que existe una relación directa o indirecta entre el animal y el ser humano ${ }^{89}$. Como ejemplo de ello la SAP de Segovia 65/1998, de 15 de Septiembre absolvió por el abandono y posterior sacrificio de un caballo por no tratarse de un animal doméstico ni ser realizado en espectáculo público, sin entrar a valorar si se trataba de maltrato, y la SAP de Madrid 117/2006, de 9 de Marzo hizo lo mismo en relación a unos gatos que frecuentaban un patio al entender que no son domésticos «los gatos que carecen de dueño y vagan por las ciudades o campos, es decir, los gatos salvajes o que viven en libertad», animales por otra parte que muchas veces son los más vulnerables ${ }^{90}$.

Su extensión a mascotas, animales de granja y destinados a la carga se basaba en razones diversas como el placer de vivir con las mascotas, la producción de alimentos u otros beneficios económicos que aportan los animales de granja o renta, y la utilización para el trabajo de los animales destinados a carga. La ampliación a partir de 2010 a los animales amansados, entendiendo como tales a aquellos que siendo silvestres o salvajes han sido dominados o adiestrados por el hombre para acostumbrarlos a su compañía, permitió que mascotas menos convencionales como iguanas o serpientes quedaran dentro de la protección penal ${ }^{91}$.

La Circular FGE 7/ 2011 de 16 de Noviembre sobre criterios para la unidad de actuación especializada del Ministerio Fiscal en materia de medio ambiente y urbanismo asumió esta ampliación al entender que animales domésticos son los que viven en compañía de las personas, si bien esa convivencia no implicaba la cohabitación, en el sentido estricto del término, sino que se trataba de un concepto más amplio que considera animal doméstico al que está habituado al contacto o relación con el hombre. Factores culturales y la normativa administrativa, fundamentalmente autonómica, de protección de animales, entre otros, serían

89 Sobre esta evolución Marqués Blanqué, M. «Art. 337» Comentarios a la reforma... cit. pág. 675 .

90 Cervelló Donderis, V. «El maltrato de animales...» cit. pág. 19.

91 ToRres FERnÁNDEZ, E. «La reforma...» cit. pág. 4. 
los elementos que habrían influido en esta ampliación del concepto de animal doméstico.

La duda sobre los animales amansados que viven en cautividad por su peligrosidad se despeja finalmente en 2015 al aclarar que los que viven bajo el control humano, aun sin ser amansados, quedan dentro de la protección, lo que incluiría a los animales de zoológicos, y en relación a los que viven en estado salvaje, sólo se protegen penalmente a los que habitualmente están domesticados, como los gatos, aunque vivan en estado salvaje $^{92}$, excluyendo al resto; esto solo deja fuera de la protección penal a los animales que viven en estado salvaje por ser su hábitat natural, por más que en su mayoría los actos de maltrato animal recaigan sobre animales claramente domésticos, como perros o gatos, y animales de granja, como caballos, cerdos u ovejas.

De esta forma, y a salvo del maltrato cruel en espectáculos públicos no autorizados, sólo los animales salvajes o silvestres han quedado fuera de la tutela penal por quedar fuera de los atributos de doméstico, amansado, animal de compañía o bajo control humano, lo que no ha conseguido tampoco cerrar el debate ya que la exclusión de los salvajes ha acabado siendo controvertida por la fuerza que va tomando su futura incorporación ${ }^{93}$ para equiparar a todos los animales vertebrados con sistema nervioso central con el argumento de que la capacidad de sufrimiento es igual a la del resto de animales, y al mismo tiempo conseguir que no se equiparen especies tan diversas de animales ${ }^{94}$.

La solución de esta forma no pasa por una remisión incondicional a las normas administrativas por la diversidad ya comentada ${ }^{95}$, ni tampoco por una inoperante relación exhaustiva de especies en el tipo penal ${ }^{96}$, sino por una interpretación en términos de intervención mínima, seguridad jurídica y ofensividad capaz de valorar la gravedad de las conductas y la capacidad de sufrimiento de los distintos tipos de animales ${ }^{97}$.

92 No lo entiende así la SAP de Murcia 123/2017, de 22 de Marzo que absuelve por el abandono de una gata callejera por exigencias de legalidad.

${ }_{93}$ Esta es la propuesta formulada por la proposición de Ley de modificación del Código penal en materia de maltrato a los animales presentada por el Grupo Parlamentario Confederal de Unidos Podemos-En Comú Podem-En marea (BOCG Congreso de los Diputados 2.2.2018) que inspirándose en la legislación alemana reclama ampliar el objeto de protección y endurecer las penas de estas figuras delictivas.

94 BRAge CENDÁN, S. «¿Es necesaria una nueva reforma penal...?» 2018 cit. págs. 7-8. Esta era la propuesta del Observatorio Justicia y Defensa animal, MARQuÉs BANQUÉ, M. «Comentario al...»2017, cit. pág. 676.

95 Hava García. E. «La protección...» 2011, cit. pág. 266. Manzanares Samaniego, J.L.«El maltrato de animales... « 2018, cit. pág. 19.

96 MuÑoz LoRenTe, J. «La protección penal...» cit. págs. 18 y 29, sin embargo, ve más adecuado incluir una definición expresa de animal doméstico en el Código penal.

97 Manzanares Samaniego. J.L. «El maltrato de animales... « cit. págs. 17 y 19. 


\subsection{El umbral del sufrimiento como elemento diferenciador}

Entre los elementos que configuran el delito de maltrato animal, la existencia de sufrimiento ha sido determinante para delimitar el círculo de las conductas delictivas. Como muestra de ello se puede citar, por un lado, el maltrato injustificado como presupuesto común de la muerte, explotación sexual o lesiones y, por otro, la no exigencia de ensañamiento en la conducta básica. En ambos sentidos se está configurando un espacio de maltrato que requiera en todo caso algún tipo de sufrimiento, pero sin elevar demasiado la intensidad del mismo.

En el primer sentido es significativo que dar autonomía a las conductas de maltrato injustificado que producen la muerte del animal no la convierte en punible en todo caso, sino que pretende diferenciar penológicamente aquellos actos de maltrato que producen dicho resultado caracterizado por su gravedad. La consecuencia es que la muerte de un animal que no sea consecuencia de una conducta de maltrato injustificado no será constitutiva del delito del art. 337.1 y 3 del Código penal, así lo estima la SAP de Barcelona 353/2018, de 15 de mayo al no poder probar que la muerte del animal fuera consecuencia de un incendio provocado pese a conocerse su presencia en la vivienda. Si bien esta interpretación pretende ser fiel al texto del Código penal, en este caso en particular, se echa en falta un mayor esfuerzo en verificar la ausencia de maltrato con circunstancias concomitantes como el cierre de las puertas de la vivienda o la ausencia de signos de violencia en el animal, que puedan indicar que no se diera el maltrato como elemento de la conducta típica.

En el segundo sentido, con la supresión en 2015 del ensañamiento como elemento del tipo básico se consiguen dos objetivos, de un lado, facilitar el castigo como delito de conductas que antes eran consideradas faltas y, de otro, endurecer las penas del tipo básico al recogerlo ahora como circunstancia agravante.

Supuestos que antes llevaran a considerar los actos de maltrato como falta por la ausencia de ensañamiento eran el abandono de animales ${ }^{98}$ o los casos de muerte rápida como la procedente de disparos con arma de fuego por su incompatibilidad con el ensañamiento ${ }^{99}$. En todos ellos, la falta de perversidad, regocijo o crueldad apartaban al maltrato de su consideración delictiva, reduciendo mucho el ámbito de aplicación por la inexistencia de un sentimiento subjetivo del autor de difícil comprobación.

Tras las reformas legales, en especial la de 2015, el abandono de animales constituye una figura típica autónoma, los casos de muerte rápida

\footnotetext{
98 ReQuejo Conde, C. La protección penal... cit. pág. 56.

99 Blanco Cordero, I. «Art. 337...»cit. págs. 1314.
} 
o instantánea se consideran también maltrato, y en caso de producirse el maltrato con especial crueldad o innecesario sufrimiento del animal se aplicaría la agravación que permite imponer la pena en su mitad superior.

\subsection{La publicidad de los actos de maltrato}

En la evolución doctrinal y jurisprudencial del tratamiento del delito de maltrato animal se observa también una ligera transformación en las conductas no autorizadas realizadas en espectáculos públicos, así como en su extensión a todos los animales, o solo a los no domésticos.

La falta del art. 632.2 CP en la redacción anterior a 2015, actualmente recogida como delito leve en el art.337.4, daba muchos problemas de interpretación por su confusa redacción, que todavía mantiene, y que puede dar a entender que incumplir un requisito formal de falta de autorización puede ser constitutivo de delito y, por el contrario, que el maltrato de animales realizado en la privacidad no es delictivo, algo como ya se ha señalado antes, insostenible. Ejemplo de ello fueron diversas sentencias absolutorias por tratarse de actos de maltrato de animales domésticos no realizados en espectáculos públicos no autorizados ${ }^{100}$.

La Jurisprudencia ha evolucionado en este sentido aceptando la protección de los animales domésticos, en todo caso, sin depender de la publicidad o no del maltrato ${ }^{101}$, imponiéndose de esta manera la postura de admitir que se castigan todos los maltratos de animales domésticos y del resto de animales, solo si se realizan en espectáculos públicos no autorizados, lo que exigirá además de la falta de autorización administrativa que se produzca un acto de maltrato cruel.

\section{Penalidad}

Las modificaciones legislativas que reflejan el proceso de transformación de los derechos de los animales tienen un claro reflejo en la evolución que ha sufrido la penalidad de estos delitos que, además de ampliar la duración de la pena de prisión y los contenidos de la pena de inhabilitación especial, ha completado sus criterios de determinación judicial con la relevancia del resultado producido y la incorporación de agravaciones específicas. En relación a las sanciones previstas para estas conductas delictivas los cambios se dirigen hacia una doble dirección: Por un lado, incrementar la pena de prisión, ya que en la redacción ac-

100 Cervelló Donderis, V. «El maltrato de animales...» cit. pág. 21.

101 Requejo Conde, C. «El delito de maltrato...» cit. pág. 24. 
tual puede llegar hasta un año en el tipo básico y hasta dieciocho meses en el tipo cualificado, lo que puede plantear la conveniencia o no de proceder a su suspensión y, de otro, ampliar la pena de inhabilitación especial para profesiones que tengan relación con animales, pena que en la actualidad se ha extendido a la tenencia de los mismos.

\subsection{Sobre el cumplimiento o suspensión de la pena de prisión}

La agravación de las penas en los delitos de maltrato animal no llega a impedir la posible suspensión de su ejecución, ya que se trata, en todo caso, de penas de menos de dos años de duración. Esta situación abre el debate sobre la necesidad de cumplimiento de la pena de prisión, dada la gravedad de las conductas y la necesidad de sensibilizar a la sociedad, con propuestas que abogan por priorizar la prevención general en su función integradora para justificar el efectivo cumplimiento de la pena ${ }^{102}$, desplazando el fundamento preventivo especial propio de esta figura suspensiva. De esta manera son ya varias las sentencias que optan por no suspender la pena por motivos de prevención general ante la alarma social que crean estas conductas y la necesidad del carácter ejemplarizante de la sanción. Especial interés suscitó la sentencia del Juzgado de lo Penal $\mathrm{n}^{\circ} 7$ de Palma Mallorca 173/2015, de 30 de abril ${ }^{103}$ y su posterior ejecutoria recogida en el Auto del Juzgado de lo Penal $\mathrm{n}^{\circ} 8$ de Palma de Mallorca, de 21 de Septiembre de 2015 por ser la primera vez que se ordenaba cumplir una pena de prisión por delito de maltrato animal ante la denegación de la suspensión de la ejecución de una pena de ocho meses de duración, para ello se aludía a la necesidad de valorar junto a la reinserción social del delincuente otros fines de la pena, en clara referencia a la prevención general.

Los argumentos recogidos en el Auto denegatorio de la suspensión de la ejecución fueron los siguientes:

«La muerte atroz de este caballo de carreras en su propia cuadra del Hipódromo, es una aberración en el siglo XXI, y la indignación ciudadana mallorquina está justificada y es legítima y por tanto la ejecución de la respuesta punitiva del Estado debe ponderar con especial interés en este caso, no solo la reinserción social del delincuente, sino los otros fines de la pena».

«Entre los principios que inspiran la ejecución penal con las debidas garantías de seguridad jurídica debemos citar la efectividad. Significa que lo

102 Ríos Corbacho, J.M. «Nuevos tiempos... « cit. págs. 44-45.

103 Comentada por Molina Domínguez, M. «Condena por la muerte del caballo »Sorky das Pont». Comentario a la s. 173/2015 del Juzgado $n^{\circ} 8$ de palma de Mallorca y del Auto de 21 de septiembre de 2015 del Juzgado no 8 de Palma, Revista de Derecho animal, vol. 6 $\mathrm{n}^{\circ} 4$ (2015). 
que se ejecuta ha de respetar lo fallado y ser enérgico si es preciso frente a la oposición del condenado y de terceros. En la práctica el automatismo con el que se conceden los beneficios quiebra en muchas ocasiones este principio».

Tras dos meses de estancia en prisión, la sección primera de la Audiencia Provincial de Palma revocó en apelación la denegación de la suspensión de la ejecución ya que, pese a compartir las valoraciones realizadas por el Juzgador sobre el rechazo social generado por la conducta del condenado, se recriminaba que no se hubieran tenido en cuenta las circunstancias personales y familiares del autor, recordando que la gravedad del delito es ponderada por el legislador al establecer las penas correspondientes, sin ser procedente realizar en este momento un nuevo juicio de gravedad y que utilizar argumentos basados en la prevención general positiva para mantener el cumplimiento en prisión, convierte al Derecho penal en un «mecanismo meramente ejemplarizante» ${ }^{104}$.

Este cambio en una decisión judicial que, en su día fue pionera, merece una breve reflexión partiendo de que el contundente rechazo a los hechos por su indiscutible gravedad, no exime de la necesidad de señalar algunas objeciones a la primera resolución denegatoria de la suspensión.

En primer lugar, en el Auto que denegó suspender el cumplimiento de una pena de ocho meses de prisión se traslada el debate sobre la proporcionalidad de las penas a la ejecución. En este sentido habría que recordar que es el Código penal al fijar la penalidad de las conductas delictivas el que está fijando un marco penal abstracto donde el juzgador marca un límite de punición en el que cabe o no la suspensión de la ejecución, por lo tanto, ya está fijando un umbral donde la menor gravedad de los hechos conforme a todos los principios penales permite tanto cumplir como no cumplir la pena de prisión.

En segundo lugar, se confunde la efectividad de la pena con su cumplimiento, olvidando que tan válido es ordenar el cumplimiento de la pena como la suspensión de la ejecución porque todo ello es hacer efectiva una pena, lo contrario es negar la función punitiva de la suspensión de la pena, especialmente cuando puede ir acompañada de prohibiciones y deberes, confundiendo no cumplimiento penitenciario con impunidad e ignorando el papel de ultima ratio que debe cumplir la pena de prisión, especialmente cuando es de corta duración.

Y en tercer lugar, priorizar en la ejecución la prevención general sobre la prevención especial representada por la reinserción social, justificando la decisión de suspender o no el ingreso en prisión en la indignación social por los hechos, la ejemplaridad sobre la sociedad, o la ne-

104 https:/www.lavanguardia.com/vida/20151204/30594172948/audiencia-de-palmalibera-al-hombre-preso-desde-octubre-por-matar-un-caballo.html 
cesidad de reforzar la conciencia de respeto a los animales ${ }^{105}$, incumple el mandato legal de valorar individualmente la necesidad de cumplir la pena de prisión, a lo que habría que añadir las posibilidades reales de tratamiento dentro y fuera de la prisión precisamente por la corta duración de la pena.

Para evitar el efecto preventivo general de la pena y sus riesgos de vulneración de la proporcionalidad, la alternativa se dirige a perseguir la concienciación y responsabilización en el mismo agresor, no en la generalidad de la sociedad, lo que implica actuar a través del carácter individualizador de la pena y su finalidad preventivo especial, lo que es mucho más garantista.

En este sentido habría que recordar que lo relevante no es el ingreso en prisión del responsable del delito, sino que la penalidad refleje la importancia del bien jurídico protegido, la gravedad de la conducta, y el reproche por los actos cometidos, por ello, hacer excepciones a la reglas de la suspensión de la ejecución no solo es un fraude de ley, sino una vulneración del principio de proporcionalidad que obliga a la excepcionalidad de las penas cortas de prisión valorando la necesidad de pena y las circunstancias personales. No es de recibo defender un Derecho Penal mínimo y humanitario que va forzando excepciones según los vaivenes sociales, como se percibe en algunas resoluciones judiciales que tratan de corregir la desproporción de la ley con una aplicación judicial discriminatoria, ya que si la prevención especial debe ser prioritaria en la fase de ejecución no pueden hacerse constantes excepciones para evitar una pretendida impunidad cuyo origen está en la fase de regulación legal.

Siguiendo la postura criticada en estas líneas, se denegó también la suspensión de la pena de un año de prisión por la comisión de un delito de maltrato animal realizado en comisión por omisión impuesta en la sentencia del Juzgado de lo Penal $\mathrm{n}^{\circ} 2$ de Palma de Mallorca 208/2015, de 28 de mayo, calificando el no cumplimiento efectivo de la pena en un delincuente primario de mensaje antipedagógico dada la gravedad y crueldad de los hechos cometidos, lo que se ratificó "por su exhaustiva motivación» por el Auto AP de Palma de Mallorca $n^{\circ} 8 / 2016$, de 19 de Enero $^{106}$. En sentido similar, la sentencia del Juzgado de lo Penal ${ }^{\circ} 1$ de Tenerife 154/2019, de 15 de Mayo, tras una extensa explicación de la función de la figura de la suspensión en la que analiza las circunstancias personales de no arrepentimiento, no reparación del daño, o crueldad de los hechos, acabó denegándola para que se cumpliera en su totalidad la pena de prisión de un año de duración por «la peligrosidad social y temor de reincidencia a tenor de la hoja histórica penal...». Sobre esta

105 Bernuz Beneitez, Mª.J. "¿Castigos eficaces...» cit. págs. 401 y 407.

106 De acuerdo con la misma se muestra Zanoguera Molinero S. en el comentario de la misma en Derecho Animal, Marzo 2016, págs. 4-6. 
afirmación habría que recordar que tan importante es incidir en la valoración de los datos individuales del sujeto para proceder o no a la suspensión de la ejecución, como que estos no entren en juicios de valor ajenos a los principios constitucionales.

Esta oposición al no ingreso en prisión en los delitos de maltrato animal se basa fundamentalmente en un error de partida como es equiparar la suspensión de la ejecución con la impunidad, lo que no es correcto ya que, como decisión potestativa, debe tratarse de adecuar la penalidad a las características del sujeto y del hecho ${ }^{107}$ evitando una concesión automática desprovista de argumentos adaptados a las necesidades del agresor. A ello debe añadirse que la suspensión puede venir acompañada de prohibiciones y deberes del listado que recoge el art. $83 \mathrm{CP}$, entre las que destaca la participación en programas formativos de protección de animales, lo que resultaría muy adecuado que, al igual que sucede en violencia de género, fuera de obligatoria imposición en los delitos de maltrato animal.

En este campo se abre una buena oportunidad para que las asociaciones defensoras de los animales presenten propuestas de programas a los servicios de gestión de penas y medidas alternativas con el fin de que se puedan ofrecer cursos de sensibilización sobre los derechos de los animales a los condenados por este delito ${ }^{108}$. El programa PROBECO ${ }^{109}$ dedicado a la intervención, sensibilización y reeducación en competencias sociales con formación general en competencias prosociales y cuatro itinerarios de los cuales uno de ellos se ocupa de la defensa de los animales, puede acompañar a las penas suspendidas como programa formativo o dotar de contenido a la pena de trabajos en beneficio de la comunidad si ha sido impuesta por aplicación del art. $84 \mathrm{CP}$.

Esta última opción recogida en el art. $84 \mathrm{CP}$ conlleva un mayor contenido punitivo ya que la suspensión de la ejecución, cumpliendo funciones de sustitución, va acompañada necesariamente de una prestación o medida que, de tratarse de la realización de trabajos en beneficio de la comunidad, obliga a realizar tareas de utilidad pública, reparar el daño o participar en programas formativos, donde encaja perfectamente el programa indicado. Además, en lo que se refiere a tareas de utilidad pública también podría consistir en el desarrollo de actividades en entidades de protección de animales sin que la prohibición del contacto con animales pueda ser un obstáculo si se garantiza que no lo hay directo, pero si indirecto, vgr. en tareas de limpieza o de ayuda a los profesionales de las ca-

107 Marqués BlanquÉ, M. «Art. 337»... cit. pág. 878.

108 Sobre estos programas, Gavilán RuBio, M. «El delito de maltrato animal. Sus penas y ejecución de las mismas. Medidas de protección animal en el proceso penal», Anuario jurídico y económico escurialense $\mathrm{n}^{\circ}$ 50, 2017, pág. 156.

109 https://unad.org/ARCHIVO/documentos/biblioteca/1452588847_programas_ tratamiento_penas_y_medidas_alternativas-myriam_tapia.pdf 
sas de recogida. La opción de acudir a la Justicia restaurativa ${ }^{110}$ también puede resultar de interés, sin que sea un obstáculo las dificultades que conlleva identificar al animal como víctima, ya que en el caso de la mediación se puede optar por acuerdos de reparación social o comunitaria o con representantes de intereses difusos como puedan ser asociaciones o entidades, y en el caso de los círculos de sentencias o conferencias familiares, la posibilidad de que participen personas diferentes al agresor y a la víctima facilita que se pueda contar con miembros de la comunidad $\mathrm{o}$ asociaciones.

La suspensión de la ejecución sirve de esta manera más óptimamente a la finalidad de reeducación y reinserción de las penas que el mero ingreso carcelario sin perder su carácter punitivo, especialmente si va acompañada de prohibiciones y deberes, ya que además de tener una mayor duración que la que hubiera tenido la pena de prisión, está sometida a distintas condiciones que, de no cumplirse, llevan a la revocación.

Las insatisfacciones que genera el automatismo de la suspensión de la ejecución de la pena en los delitos de maltrato animal, que habitualmente conduce al no ingreso en prisión, puede dar lugar a dos respuestas bien diferentes. En la primera de ellas se opta por reivindicar la opción de la vía administrativa por su mayor eficacia frente a la penal ${ }^{111}$, en la segunda, sin embargo, se elige agravar la penalidad con el fin de asegurar el ingreso efectivo en prisión ${ }^{112}$, lo que no solo no se alinea con la interpretación restrictiva de estas conductas que propugna la mayoría de la doctrina penal, sino que olvida los problemas que generan las penas de corta duración y sus dificultades para el tratamiento intrapenitenciario, e ignora que las medidas alternativas concedidas de forma individualizada y dotadas de contenidos específicos, al actuar más allá del carácter meramente aflictivo de la pena de prisión, pueden facilitar la educación y sensibilización caracterizados por ser señalados como los instrumentos más útiles y eficaces para prevenir estas conductas delictivas ${ }^{113}$. Por todo ello la solución pasa por evitar el automatismo de la suspensión de la ejecución de la pena con una concesión debidamente fundamentada sin que la prevención general reemplace como criterio rector a la prevención especial.

110 Bernuz Beneitez, Mª.J. «¿Castigos ...»cit. pág. 414.

111 MuÑoz LoRENTE, J. «La protección penal...»cit. pág. 34.

112 Propuesta defendida por el Observatorio de Justicia y defensa animal y recogida en la Proposición de ley de reforma del Código Penal de 26 de Enero de 2018 donde se planteaba elevar a tres años la pena de prisión en este delito.

113 Bernuz Beneitez, $\mathbf{M}^{\mathrm{a}}$.J. «¿ Castigos (eficaces) ...? »cit. pág. 419. 


\subsection{Inhabilitación especial en relación a los animales}

La pena de inhabilitación especial contemplada en los delitos de maltrato animal también se encuentra en un proceso de cambio ya que desde su inicial alcance limitado a la prohibición del ejercicio de profesión, oficio o comercio que tenga relación con los animales ha pasado a incorporar la prohibición de la tenencia, lo que para un sector es insuficiente, reclamando que abarque también la privación definitiva del animal con la finalidad de impedir su recuperación tras el cumplimiento de la condena de inhabilitación ${ }^{114}$.

Hay que diferenciar el art. $337 \mathrm{CP}$ que castiga los delitos de maltrato animal donde la inhabilitación especial para el ejercicio de profesión, oficio o comercio que tenga relación con los animales y la tenencia de animales es de obligatoria imposición, del art. 337 bis CP que regula el delito de abandono de animales donde tiene carácter potestativo, lo que obliga a fundamentar en este segundo caso la necesidad de su imposición. La motivación de las penas potestativas conlleva la obligación de justificar su imposición, algo que en ocasiones se olvida provocando su revocación, como sucede en la SAP de Valencia 20/2018, de 12 de Enero y en la SAP de Álava 383/2018, de 28 de Diciembre, mientras que en otros casos, como la SAP de León 501/2016, de 7 de Noviembre, se apoya su imposición en «el altísimo riesgo para la vida del animal dadas las condiciones que concurrieron en el abandono», o la SAP de Valencia 602/2018, de 16 de Noviembre en que se tratara precisamente de un profesional de la atención y cuidado de los animales.

Son dos son los posibles contenidos de esta pena de inhabilitación en la actualidad:

a) prohibición del ejercicio de profesión, oficio o comercio que tenga relación con los animales

b) prohibición de la tenencia de animales

En relación a la prohibición del ejercicio de profesión, oficio o comercio que tenga relación con los animales se trata de una pena que puede imponerse a cualquier persona con independencia de que profesionalmente se ocupe o no de animales ya que, como en toda privación de derechos, la prohibición consiste tanto en despojar de esta facultad, como impedir que se pueda obtener durante el tiempo de la condena. La profesión puede consistir en cualquier actividad u oficio que tenga relación con animales lo que le dota de una gran amplitud que, de no concretarse judicialmente, puede impedir actividades tan dispares como la crianza

114 Brage CEndán, S. «¿Es necesaria una nueva reforma penal ...?» cit. pág. 12 lo propone solo para los tipos más graves. 
de animales, las actividades en mataderos o la venta o distribución en el sector de alimentación ${ }^{115}$.

La prohibición de la tenencia de animales ha sido una novedad muy bien recibida para evitar cualquier contacto con animales durante el cumplimiento de esta pena, al no alcanzar la privación de actividades profesionales a la tenencia particular. Hay que tener en cuenta que al tratarse de un delito común no sólo no es necesario cometerlo en la práctica de una profesión, sino que incluso es frecuente que el maltrato se produzca fuera de ella ${ }^{116}$, por eso se trata de impedir cualquier tipo de contacto con animales al margen de las actividades profesionales, si bien es cierto que con ello tampoco se impide que, tras su cumplimiento, el sujeto vuelva a disponer de animales, lo que plantea dudas respecto a su contenido, alcance y duración.

En relación a su contenido, la prohibición de la tenencia de animales literalmente sólo afecta a dicho título jurídico, por lo tanto no abarca la mera convivencia en el mismo domicilio como reclamaba parte de la doctrina, y aunque sea cierto que ello pueda afectar a otros miembros de su entorno más próximo, bien sea en los supuestos de violencia domésti$\mathrm{ca}^{117}$ como en otros casos de convivencia compartida con animales, ello evitaría que, suprimida la tenencia como título jurídico de posesión del animal, se mantuviera cualquier contacto con el animal maltratado, por eso se puede plantear la opción de imponerlo como deber impuesto por el Juez de los recogidos en el art. 83.9 CP en las penas suspendidas.

Precisamente porque no está contemplada la retirada del animal se puede dar el caso de que el dueño del animal mientras dure el proceso mantenga su posesión o, incluso al terminar de cumplir la pena de prohibición de tenencia recupere ese u otros animales ${ }^{118}$, todo ello puede servir de argumento para plantearse la posibilidad de ampliar la penalidad del delito de maltrato animal con la privación definitiva del mismo. La Proposición de Ley de modificación del Código penal en materia de maltrato a los animales antes mencionada de 26 de Enero de 2018, apuesta por privar definitivamente de la propiedad o posesión sobre el animal que haya sido víctima de maltrato para protegerles de quienes hayan estado obligados a su cuidado.

Dentro de las consecuencias jurídicas del delito mención aparte merece el decomiso, figura destinada a recoger los instrumentos o efectos del delito con el fin de que el condenado no siga disponiendo de los

115 Una opción es limitarlo a profesiones con animales vivos y no muertos como en pescaderías o carnicerías, MuÑoz LORENTE, J. «La protección penal...» cit. pág. 34.

116 MuÑoz LoRENTE, J. «La protección penal...» cit. pág. 35.

117 Requejo Conde, C. «El delito de maltrato...» cit. pág. 21.

118 CuERda ARNAU, $\mathrm{M}^{\mathrm{a}} . \mathrm{L}$ «Inhabilitación especial tenencia de animales» en Comentarios a la reforma del Código Penal de 2015, $2^{\mathrm{a}}$ Ed, Dtor. J.L. González Cussac, Tirant lo Blanch, Valencia, 2015, pág. 241. 
mismos, ya que su naturaleza eminentemente económica impide conceptualmente que se aplique en los delitos de maltrato animal, lo que supone que no se pueda recoger en sentencias penales. Ello no impide, sin embargo, que desde sectores animalistas se reivindique su imposición cautelar para garantizar la seguridad del animal que haya sido objeto de maltrato, lo que en vía administrativa está previsto, pero queda sin resolver en la vía penal ${ }^{119}$.

\section{Conclusiones}

La sensibilización social ante los actos de maltrato animal ha sufrido una evidente evolución derivada de la autocrítica sobre la ética del comportamiento de los humanos en sus relaciones de convivencia con los animales, y de la necesidad de orientar la resolución de conflictos sociales entre seres humanos y animales hacia la ponderación de derechos e intereses recíprocos.

El abandono de las posturas antropocentristas que cosifican a los animales como mero instrumento al servicio de los intereses humanos, $\mathrm{y}$ el auge de las fieles a un biocentrismo moderado que reconoce derechos autónomos a la especie animal, han llevado a que la regulación del delito de maltrato animal se vaya aproximando a la del delito de lesiones con una estructura muy semejante que distingue los delitos de maltrato animal básico de distintas agravaciones por el resultado o los medios empleados, lo que además de mejorar la tutela de los derechos de los animales, permite compartir criterios de interpretación.

Muy significativa ha sido también la ampliación a todo tipo de animal, a excepción de los salvajes, lo que nos aleja tangencialmente de los orígenes del delito vinculado a los animales domésticos de compañía, para acabar albergando a todo animal que tenga relación directa o indirecta con los seres humanos.

Todo ello puede contribuir a combatir el negacionismo y a disipar las iniciales dudas sobre el bien jurídico protegido, al consolidarse el reconocimiento del bienestar animal como objeto de protección, pero también debe servir para contener las tendencias expansivas que solo confían en la pena de prisión como respuesta punitiva. Por ello, mantener un umbral penológico que permita la suspensión de la ejecución y fomentar la

119 Vercher Noguera, A. «Algunas reflexiones sobre la evolución del delito de maltrato a animales domésticos y la posibilidad de decomiso de los mismos», Diario La Ley n ${ }^{\circ} 9527$ de 27 de Noviembre de 2019, pág. 8 citando diversos Autos judiciales que reaccionando ante la pasividad administrativa para garantizar la seguridad de los animales aplican incorrectamente el decomiso administrativo en la vía judicial penal. 
pena de inhabilitación especial que impida el contacto con animales puede ser una respuesta mucho más adecuada en términos resocializadores.

\section{Bibliografía}

Arribas Atienza, P. «El nuevo tratamiento civil de los animales» Diario La Ley n ${ }^{\circ}$ 9136, 9 de febrero de 2018.

Baucells Lladós, J. "Comentarios al art. 337» Comentarios al Código Penal Parte Especial. Dtores. J. Córdoba Roda/M.García Arán Marcial Pons, Madrid, 2004.

BERnUz BENEITEZ, $\mathrm{M}^{\mathrm{a}} \mathrm{J}$ «El maltrato animal como violencia doméstica y de género. Un análisis sobre las víctimas» Revista de victimología $\mathrm{n}^{\circ}$ $2 / 2015$.

BERnuz Beneitez, $M^{\mathrm{a}}$.J. « ¿Castigos (eficaces) para delitos contra los animales? Repensando la respuesta al maltrato animal» In Dret 1.2020.

Blanco Cordero, I. «Art. 337» en Comentarios prácticos al Código penal Tomo IV Dtor. Gómez Tomillo, Aranzadi, Cizur menor, 2015.

Brage Cendán, S. Los delitos de maltrato y abandono de animales (artículos 337 y 337 bis CP) Tirant lo Blanch, Valencia, 2017.

Brage Cendán, S. «¿Es necesaria una nueva reforma penal en el ámbito de los delitos de maltrato y abandono de animales?» Diario La ley $\mathrm{n}^{\circ}$ 9187, 27 de Abril de 2018.

Cavalier,P.-Singer, P. (Edición de) El proyecto gran simio. La igualdad más allá de la humanidad. Trad. C. Martín y C. González Ed. Trotta,Valladolid, 1998.

Cervelló Donderis, V. «El maltrato de animales en el Código penal español» Revista General de Derecho penal n ${ }^{\circ}$ 10, 2008.

CERVelló Donderis, V. «El Derecho penal ante el maltrato de animales» Cuadernos de Derecho Penal n 15, Enero-Junio 2016.

Cuerda Arnau, $\mathrm{M}^{\mathrm{a}}$. L. "Maltrato y abandono de animales» Comentarios a la reforma del Código Penal de 2015, 2ª Ed Dtor J.L. González Cussac, Tirant lo Blanch, Valencia, 2015.

- «Inhabilitación especial tenencia de animales» Comentarios a la reforma del Código Penal de 2015, 2ª Ed DTOR J.L. González Cussac, Tirant lo Blanch, Valencia, 2015.

De Lucas Martín, J. «En el bicentenario de Darwin ¿derechos de los animales no humanos? La barrera de la dignidad» Teoría \& Derecho $\mathrm{n}^{\circ}$ 6, 2009.

De Santiago FernándeZ, L. «El maltrato animal desde un punto de vista criminológico» Derecho y cambio social, Año 10, nº 33, 2013. 
Del Campo Álvarez, B. «El nuevo estatus jurídico de los animales y su incidencia en los casos de separación y divorcio»Diario La Ley $\mathrm{N}^{\circ}$ 9207, 29 de Mayo de 2018.

DuRÁn SECO, I. «El maltrato y abandono de animales desde el punto de vista del Derecho penal (L.O. 1/2015 de 30 de Marzo)» Libro-Homenaje a Claus Roxin por su nombramiento Doctor h.c. por la Universidad Inca Garcilaso de la Vega, Dtor. D.M Luzón Peña, Lima 2018.

FERNÁNDEZ Álvarez, A. «Protocolo clínico de identificación de maltrato animal» Revista general de derecho animal y estudios interdisciplinares de bienestar animal (2017).

Gavilán Rubio, M. «El delito de maltrato animal. Sus penas y ejecución de las mismas. Medidas de protección animal en el proceso penal». Anuario jurídico y económico escurialense $\mathrm{n}^{\circ}$ 50, 2017.

Hava García, E. «La protección del bienestar animal a través del Derecho penal» Estudios penales y criminológicos vol XXI (2011).

Higuera Guimerá, J.F. «Los malos tratos crueles a los animales en el CP 1995». Actualidad Penal no 17, 1998.

Jabato Martín, A. «Art. 337 bis» Comentarios prácticos al Código penal Tomo IV Dtor. Gómez Tomillo, Aranzadi, Cizur Menor, 2015.

JaURRIETA ORTEga. I. «El bien jurídico protegido en el delito de maltrato animal» Revista de Derecho UNED n 24, 2019.

JimÉNEz LóPEz, I. Violencia sexual contra animales. Universidad Autónoma de Barcelona, Barcelona, 2019.

KRONHARDt SchefFer, G. "Animal abuse: a close realtionship with domestic violence» Derecho Animal, 2019, vol. 10/2.

Lockwood, R. Touroo, R. Olin, J. Dolan, E. «The influence of evidence on animal cruelty prosecution an case outcomes: results of a survey» Journal of forensic sciences Noviembre 2019, 64 (6).

Magaldi Paternostro, $\mathrm{M}^{\mathrm{a}}$.J. «Art. 632» Comentarios al Código Penal Parte Especial. Dtores. J. Córdoba Roda/M.García Arán, Marcial Pons, Madrid, 2004.

MANZANARES SAMANIEGo, J.L»El maltrato de animales en el Ordenamiento penal español: una visión sistemática» Revista General de Derecho animal y Estudios interdisciplinares de Bienestar Animal 1 (2018).

Marqués Blanqué, M. «Comentario al art. 337»Comentarios al Código Penal español Tomo II. Dtor. G. Quintero Olivares $7^{\mathrm{a}}$ Ed. Thomson Reuters, Barcelona, 2017.

— «Comentario al art. 337» Comentario a la reforma penal de 2015. Dtor. G. Quintero Olivares, Aranzadi, Pamplona 2015.

Martínez Buján, C. Derecho Penal Parte Especial 6 ${ }^{a}$ Ed. Coord. J.L González Cussac, Tirant lo Blanch, Valencia, 2019. 
MenÉndez De Llano RodRíGuez, N. «Evolución de la sanción penal por maltrato animal: el caso español» Diario La Ley n 9038,11 de Septiembre de 2017.

Molina Domínguez, M. «Condena por la muerte del caballo «Sorky das Pont». Comentario a la s. 173/2015 del Juzgado $\mathrm{n}^{\circ} 8$ de palma de Mallorca y del Auto de 21 de septiembre de 2015 del Juzgado n ${ }^{\circ} 8$ de Palma. Revista de Derecho animal vol. $6 \mathrm{n}^{\circ} 4$ (2015).

Mosterín, J. Animales y ciudadanos Ed. Talasa, Madrid, 1995.

Muñoz Conde, F. Derecho Penal Parte Especial 21 a Ed. Tirant lo Blanch, Valencia, 2017.

Muñoz LoRente, J. «La protección penal de los animales domésticos frente al maltrato" La ley penal: revista de derecho penal, procesal y penitenciario $\mathrm{n}^{\circ} 42,2007$.

Muñoz Machado, S. y otros Los animales y el Derecho. Civitas, Madrid, 1999.

Olmedo de la Calle. E. Los delitos de maltrato animal Tesis doctoral inédita, Valencia, 2017.

Pelayo González Torre, A. «Sobre los derechos de los animales» Anuario de Filosofía del Derecho $\mathrm{n}^{\circ}$ 7, 1990.

Prats Canut, J.M.-Marques Banque, M. Comentarios al Nuevo Código Penal. Dtor G. Quintero Olivares 3ª Ed, Navarra, 2004.

Requejo Conde, C. La protección penal de la fauna. Especial consideración del delito de maltrato de animales. Comares, Granada 2010. Disponible en https://es.slideshare.net/margyed/requejo-capitulolibroelmaltratodeanimales.

- «El delito de maltrato a los animales tras la Reforma del Código PENAL POR LA LEY ORGÁNICA 1/2015 DE 30 DE MARZO» DERECHO ANIMAL (ForUm of ANimal LAW StUdies) vol 6 No 2 (2015) HTTPS://REVISTES. uab.cat/da/article/view/v6-n2-requejo/77.

Ríos Corbacho. J.M. «Nuevos tiempos para el delito de maltrato de animales a la luz de la reforma del Código penal español ( L.O. 1/2015)» Revista electrónica de Ciencia Penal y Criminología 18-17 (2016).

- «Los animales como Posibles sujetos De DeRecho Penal. Algunas referencias sobre los artículos 631 (suelta de animales feroces o dañinos) y 632 (malos tratos crueles) del Código Penal español». Revista de Derecho penal de la Universidad de Friburg. https://www.unifr.ch/ddp1/ derechopenal/articulos/a_20080526_86.pdf

Roca Agapito, L. «Algunas reflexiones sobre los animales y el Derecho Penal. En particular el Art.631 del Código Penal». Actualidad Penal $\mathrm{n}^{\mathrm{o}} 18,2000$. 
SALT, H.S. Los derechos de los animales. Trad. por C.Martín y C.González. Introducción de J.Mosterín, Madrid, 1999.

SERrano TÁrraga, $M^{\mathrm{a} D}$. «El maltrato de animales en el Código Penal» Diario La Ley nº274, 14 de Junio de 2005.

TORRES FERNÁNDEZ, E. "La reforma del delito de maltrato a los animales» Diario La Ley $\mathrm{n}^{\circ}$ 7534, 23 de Diciembre de 2010.

VERCHer Noguera, A. «Nuevas perspectivas sobre el bien jurídico protegido en los delitos ambientales: ¿cabría hablar de derechos no humanos de los animales domésticos frente a su maltrato?» Diario La Ley $\mathrm{n}^{\mathrm{o}} 8994,2017$.

VVAA Monográfico «Los derechos de los animales»Teoría\&Derecho $\mathrm{n}^{\circ}$ 6/2009.

Zapico Barbeito, M. «Hacia un nuevo bien jurídico del delito de maltrato de animales domésticos o amansados» Revista de Derecho y proceso penal $\mathrm{n}^{\mathrm{o}} 25,2011$. 
